DESAIN SISTEM INFORMASI PEMINJAMAN SARANA

PRASARANA BERBASIS MOBILE DI KWARTIR LAMPUNG

PENULISAN ILMIAH

Oleh

WINA SAGITA

16411021

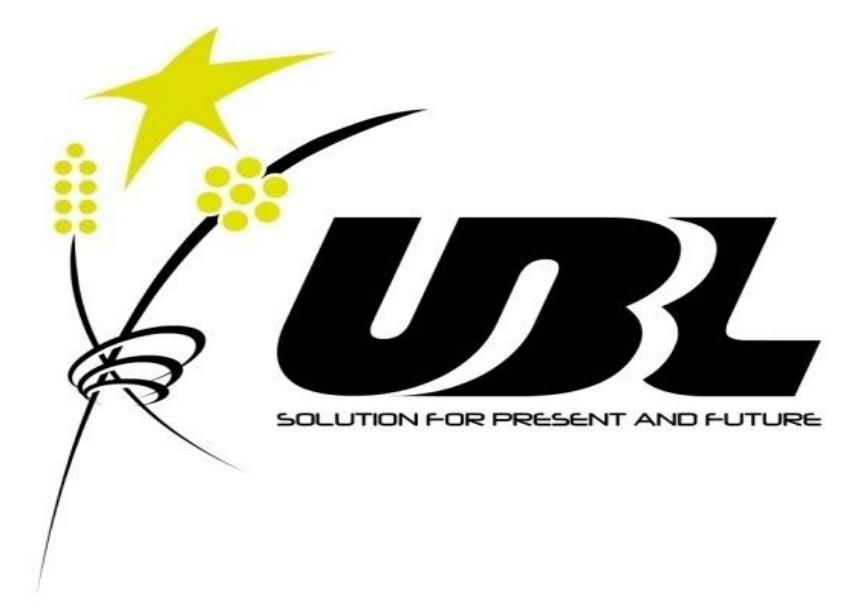

PROGRAM STUDI SISTEM INFORMASI

FAKULTAS ILMU KOMPUTER

UNIVERSITAS BANDAR LAMPUNG

2019 


\section{DESAIN SISTEM INFORMASI PEMINJAMAN SARANA PRASARANA BERBASIS MOBILE DI KWARTIR LAMPUNG}

\section{PENULISAN ILMIAH}

Diajukan Sebagai Salah Satu Syarat untuk Mengambil Tugas Akhir Kesarjanaan Strata-1 (S1) pada Program Studi Sistem Informasi Fakultas Ilmu Komputer

Universitas Bandar Lampung

Oleh

WINA SAGITA

16411021

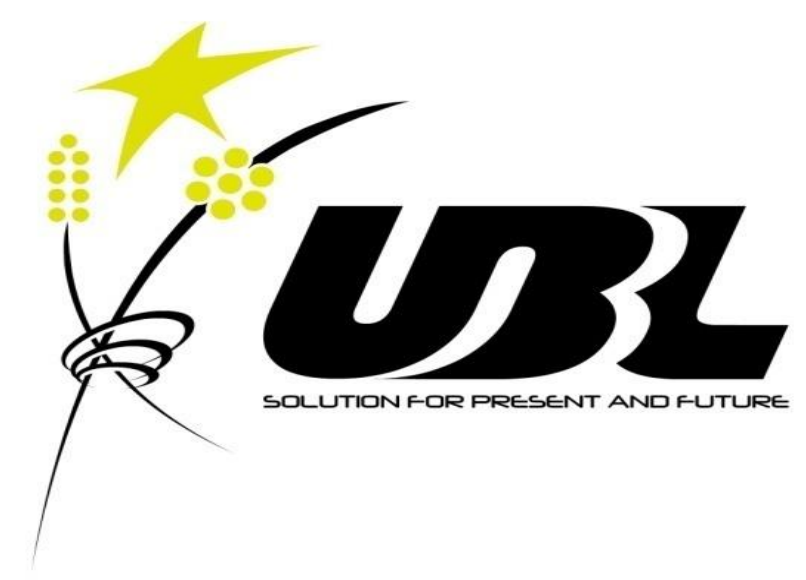

PROGRAM STUDI SISTEM INFORMASI

FAKULTAS ILMU KOMPUTER

UNIVERSITAS BANDAR LAMPUNG

2019 


\section{LEMBAR PENGESAHAN}

Judul Penulisan Ilmiah

Nama Mahasiswa

No.Pokok Mahasiswa

Program Studi

Fakultas
: DESAIN SISTEM INFORMASI PEMINJAMAN

SARANA PRASARANA BERBASIS MOBILE DI KWARTIR LAMPUNG

: WINA SAGITA

: 16411021

: Sistem Informasi

: llmu Komputer

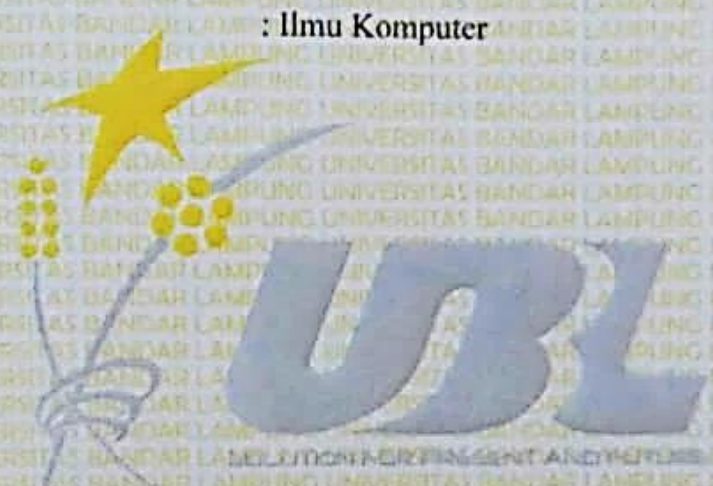

Bandar Lampung, Agustus 2019

MENGESAHKAN

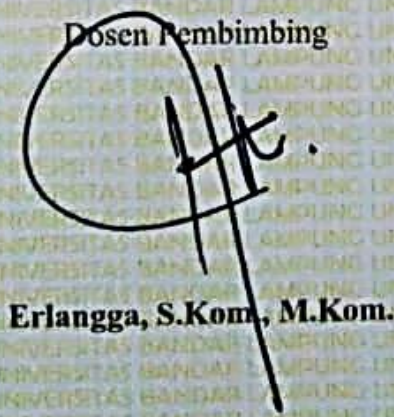

Ketua Program Studi

Sistem Informasi

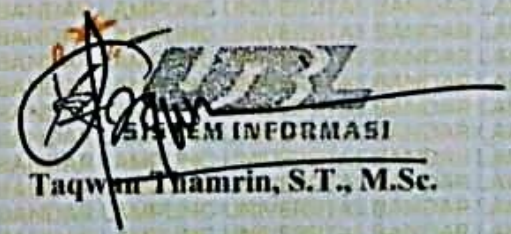

ii

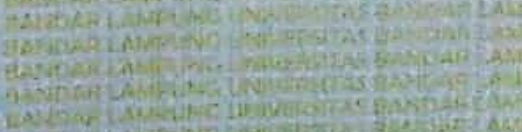




\section{MENGESAHKAN}

Tim Penguji

Ketua

Ketua

Penguji Utama : Ahmad Cucus, S.Kom., M.Kom.

Penguji 1

: Fenty Ariani, S.Kom., M.Kom.

Penguji 2

: Taqwan Thamrin, S.T., M.Sc.

\section{Tanlia Tangan}

h.

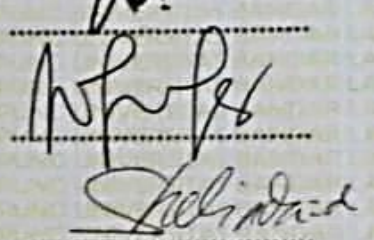

\section{MENGETAHUI}

Dekan Fakultas. IImu Komputer

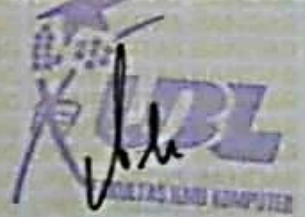

Ahmad Cucus, S.Kom., M.Kom.

Tangeal Lulus Seminar Agustus 2019 


\title{
ABSTRAK \\ Desain Sistem Informasi Peminjaman Sarana Prasarana Berbasis Mobile di Kwartir Lampung
}

\author{
oleh
}

Wina Sagita

16411021

\begin{abstract}
Berkemah adalah kegiatan di luar ruangan yang jauh dari lingkungan perkotaan yang sibuk. Berkemah biasanya dilakukan oleh anggota Pramuka dan organisasi lainnya. Namun tidak jarang masyarakat kesulitan mencari tempat perkemahan dan alat-alat untuk berkemah dalam melakukan kegiatan berkemah. Terkadang, calon pengguna harus menghubungi administrator kamp untuk mengetahui apakah tempat perkemahan sedang digunakan atau kosong. Hal ini terjadi karena proses peminjaman tempat perkemahan di Kwartir Lampung saat ini masih dilakukan secara manual. Untuk itu dilakukan analisis terhadap perancangan sistem informasi peminjaman infrastruktur di Kwartir Lampung. Perancangan aplikasi ini menggunakan Android Studio. Dengan menganalisis rancangan sistem informasi pinjaman fasilitas ini, masyarakat lebih mudah dalam mengakses informasi lokasi kamping di Provinsi Lampung beserta informasi ketersediaan, fasilitas, dan informasi lainnya.
\end{abstract}

Kata Kunci: Bumi Perkemahan, Sistem Informasi Fasilitas, Sarana Prasarana, Berkemah, Pramuka 


\section{ABSTRACT \\ DESIGN OF LENDING INFORMATION SYSTEMS FOR MOBILE-BASED INFRASTRUCTURE FACILITIES IN LAMPUNG KWARTIR}

by

Wina Sagita

16411021

Camping is an outdoor activity away from the busy urban environment. Camping is usually carried out by members of scouts and other organizations. However, it is not uncommon for people to find it difficult to find campsites and tools for camping in carrying out camping activities. Sometimes, potential users have to contact the camp administrator to find out if a campsite is in use or empty. This happens because the process of borrowing campsites in Kwartir Lampung is currently still done manually. For this reason, an analysis of the design of information systems for borrowing infrastructure in the Lampung Quarter was carried out. The design of this application uses Android Studio. By analyzing the design of this facility loan information system, it is easier for the community to access information on camping locations in Lampung Province along with information on availability, facilities, and other information

Keywords: Campground, Facility Information System, Infrastructure, Camping, Scout 


\section{DAFTAR ISI}

\section{COVER}

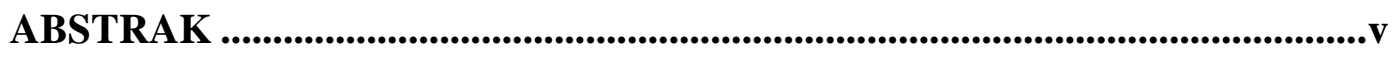

DAFTAR ISI............................................................................................................ vii

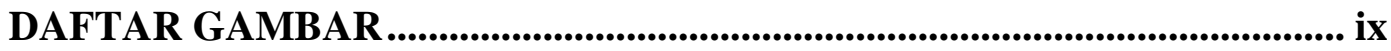

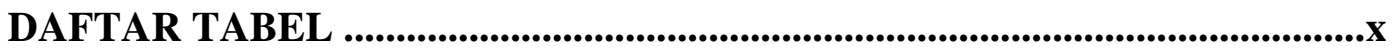

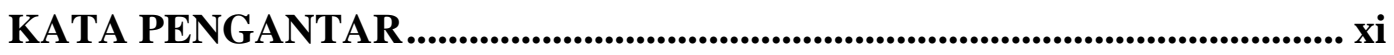

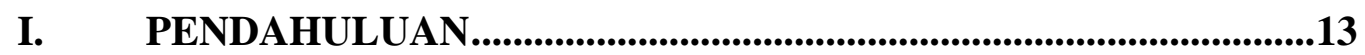

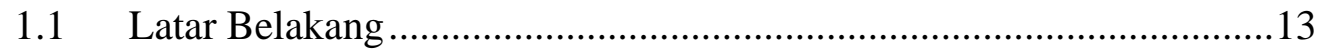

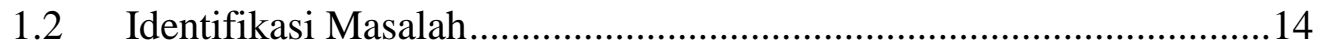

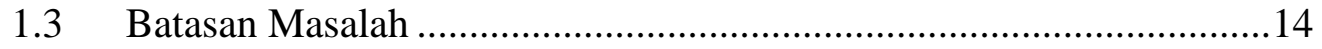

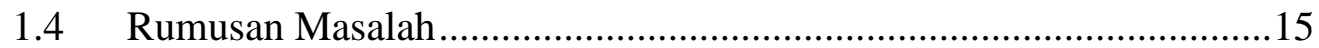

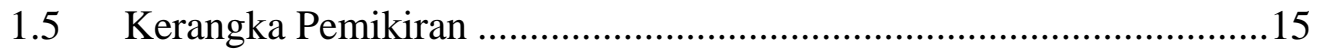

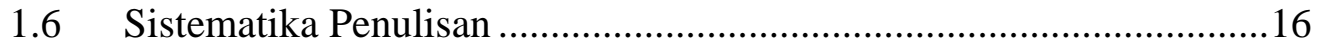

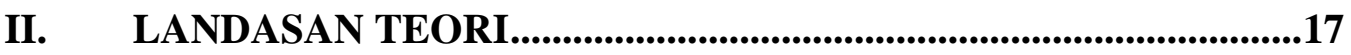

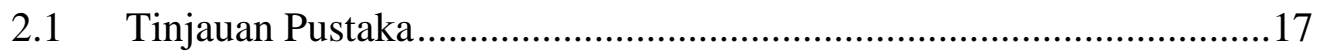

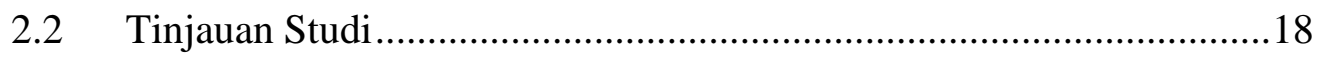

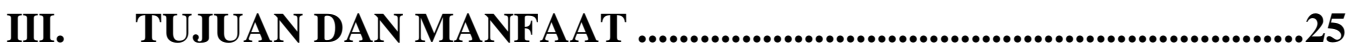

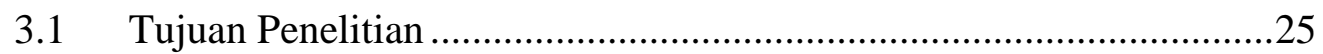

3.2 Manfaat Penelitian .............................................................................25

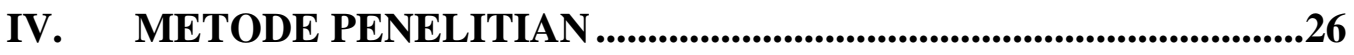

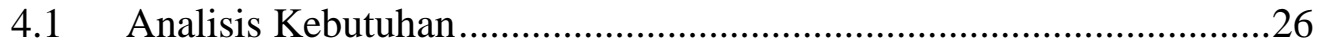

4.2 Metode Pengumpulan Data..........................................................2

V. HASIL ANALISIS DAN PEMBAHASAN ......................................30 


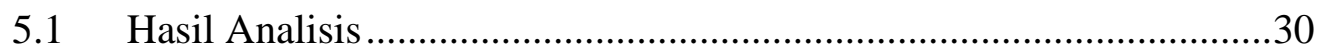

5.2 Langkah - Langkah Pembuatan Aplikasi ............................................32

VI. RENCANA PENELITIAN BERIKUTNYA_.....................................36

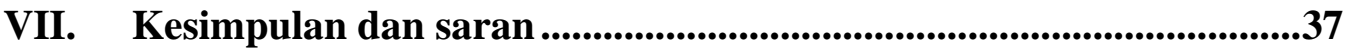

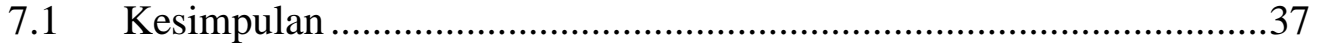

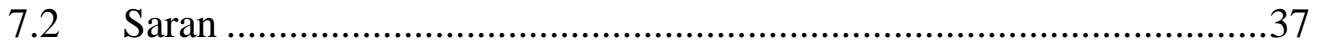

DAFTAR PUSTAKA

LAMPIRAN 


\section{DAFTAR GAMBAR}

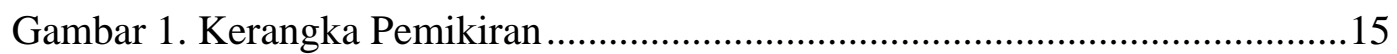

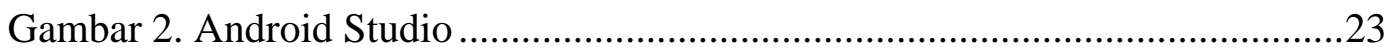

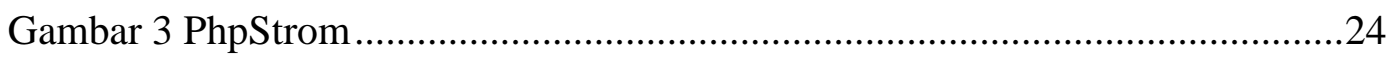

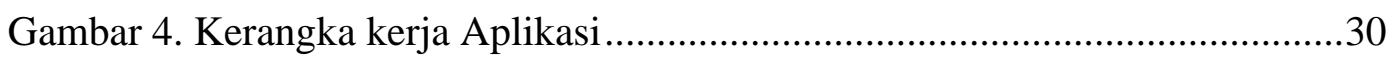

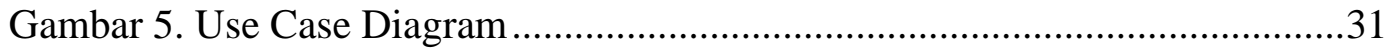

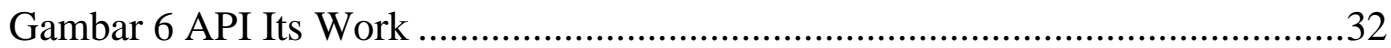

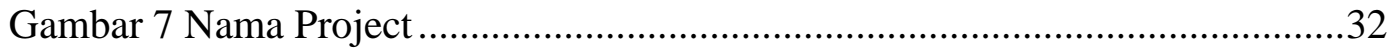

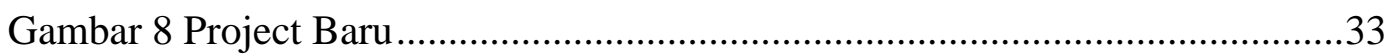

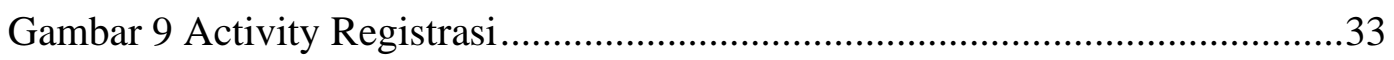

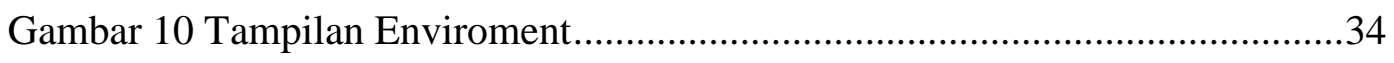

Gambar 11 Tampilan Menu Login.........................................................................

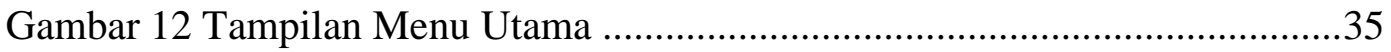




\section{DAFTAR TABEL}

Table 1. Bumi Perkemahan Provinsi Lampung ................................................22

Table 2 Fasilitas Buperda Lampung ............................................................28

Table 3 Biaya Fasilitas Buperda Lampung ...................................................28 


\section{KATA PENGANTAR}

Puji dan syukur penulis panjatkan ke hadirat Allah SWT, yang telah memberikan izin dan kekuatan, sehingga penulis dapat menyelesaikan Penulisan Ilmiah ini dengan judul "Desain Sistem Informasi Peminjaman Sarana Prasarana Berbasis Mobile di Kwartir Lampung" tepat pada waktunya. Penulisan Ilmiah ini dibuat sebagai salah satu syarat untuk dapat mengambil Tugas Akhir atau Skripsi.

Penulis menyadari bahwa dalam pembuatan Penulisan Ilmiah ini tidak terlepas dari bantuan dan bimbingan dari semua pihak sehingga Penulisan Ilmiah dapat diselesaikan dengan baik. Dengan ini penulis mengucapkan terima kasih kepada:

1. Ibu Dra. Hj. Sri Hayati Barusman selaku Ketua Pembina Yayasan Administrasi Universitas Bandar Lampung.

2. Bapak Dr. Ir. H. Yusuf Sulfarano Barusman, M.B.A. selaku Rektor Universitas Bandar Lampung.

3. Bapak Dr. Andala Rama Putra Barusman, S.E., MA.Ec. selaku Direktur Eksekutif Yayasan Universitas Bandar Lampung.

4. Bapak Ahmad Cucus, S.Kom., M.Kom. selaku Dekan Fakultas Ilmu Komputer Universitas Bandar Lampung.

5. Bapak Taqwan Thamrin, S.T., M.Sc. selaku Ketua Program Studi Sistem Informasi Fakultas Ilmu Komputer Universitas Bandar Lampung.

6. Bapak Marzuki, S.Kom., M.Kom. selaku Ketua Program Studi Teknik Informatika Fakultas Ilmu Komputer Universitas Bandar Lampung.

7. Bapak Erlangga, S.Kom.,M.TI. selaku pembimbing akademik sekaligus pembimbing dalam Penulisan Ilmiah ini yang telah membimbing, memberikan pengarahan dalam menyelesaikan penulisan ilmiah ini.

8. Seluruh dosen dan staff pengajar Fakultas Ilmu Komputer Universitas Bandar Lampung.

9. Orang tua tercinta di rumah yang selalu mendukung dan memberi semangat.

10. Teman-teman Program Studi Sistem Informasi angkatan 2016 Fakultas Ilmu Komputer Universitas Bandar Lampung. 
11. Teman-teman pengurus Himpunan Mahasiswa Sistem Informasi (HMSI) Fakultas Ilmu Komputer Universitas Bandar Lampung.

12. Seluruh pihak yang telah membantu penulis dalam menyelesaikan Penulisan Ilmiah ini.

Penulis menyadari bahwa hasil Penulisan Ilmiah ini masih banyak kekurangan dan kelemahannya, baik dalam isi maupun sistematikanya. Oleh sebab itu, penulis sangat mengharapkan kritik dan saran untuk menyempurnakan penulisan ini. semoga hasil Penulisan Ilmiah ini dapat memberikan manfaat, khususnya bagi penulis dan umumnya bagi pembaca.

Bandar Lampung, 29 Agustus 2019 Wina Sagita 


\section{PENDAHULUAN}

\subsection{Latar Belakang}

Perkembangan teknologi telah berkembang sangat pesat hingga sekarang. Dari yang sederhana, hingga yag mutakhir. Diberbagai negara maju dan negara berkembang, hadir teknologi-teknologi baru yang dapat membantu kita dalam hal pekerjaan (Tri Senjaya, 2019). Saat ini hampir semua tempat dipenuhi dengan hal-hal yang berbau teknologi. Hal ini dapat dibuktikan dengan penggunaan gadget pribadi yang tak terhitung jumlahnya, jenis, dan kisaran harga yang beragam. Gadget tersebut bisa berupa komputer laptop yang bisa dibawa kemanamana dan ponsel yang lebih ringkas dari laptop yang juga fungsinya hampir sama dengan komputer

(Erlangga \& Dharmawan, 2017).

Berkemah merupakan kegiatan rekreasi diluar ruanganan yang umumnya dilakukan untuk menghilangkan penat dari ramainya perkotaan, atau dari keramaian secara umum dengan tujuan untuk dapat menikmati keindahan alam. Kegiatan ini bisa dilakukan oleh berbagai kalangan masyarakat, mulai dari kelompok siswa sekolah, mahasiswa, dan organisasi-organisasi lainnya (Suhenda \& Hirawan, 2018). Banyaknya lokasi bumi perkemahan di Indonesia khususnya di Provinsi Lampung membuat masyarakat lokal, pelajar, dan organisasi-organisasi ingin melakukan kunjungan ke bumi perkemahan yang disajikan oleh setiap kota. Hal ini menjadi sulit pada saat pencarian lokasi tempat berkemah dikarenakan belum adanya penyajian informasi lokasi bumi perkemahan secara akurat (Syahputra, 2014).

Peminjaman sarana prasarana di bumi perkemahan (buper) di Kwartir Daerah Lampung tersebut masih dilakukan secara manual yaitu dengan cara menghubungi pihak yang terkait atau datang ke tempat tersebut lalu melakukan proses peminjaman bumi perkemahan sesuai dengan prosuder yang dibuat oleh pengelolah tempat tersebut. Begitu juga untuk mengetahui ketersedian fasilitas yang ada di Bumi Perkemahan.

Untuk membantu masyarakat dalam hal peminjaman sarana prasarana, maka diperlukan adanya aplikasi peminjaman untuk sarana dan prasarana di bumi 
perkemahan. Dengan memanfaatkan perangkat mobile tersebut, maka penulis akan membuat sebuah aplikasi peminjaman sarana prasarana di bumi perkemahan yang berbasis Android. Aplikasi ini nantinya dapat menampilkan informasi dan persyaratan mengenai peminjaman sarana prasarana tersebut. Hal ini dilakukan selain untuk efesiensi dan efektifitas dari proses peminjaman fasilitas Buper juga untuk meminimalkan penggunaan kertas karena teknologi dan administrasi paperless adalah suatu hal yang sangat efisien dalam penggunaan kertas, terutama dalam hal dokumen dan surat menyurat untuk mencapai tujuan tertentu dalam mengelola sistem manajemen administrasi atau ide kantor tanpa kertas (Susanty et al, 2014). Berdasarkan uraian diatas, maka penulis ingin melakukan penelitian dalam penulisan ilmiah yang berjudul "Desain Sistem Informasi Peminjaman Sarana Prasarana Berbasis Mobile di Kwartir Lampung”.

\subsection{Identifikasi Masalah}

Berdasarkan latar belakang diatas identifikasi masalah yang muncul didalam penelitian ini yaitu:

a. Minimnya informasi mengenai lokasi peminjaman sarana prasarana di bumi perkemahan di Kwartir Daerah Lampung.

b. Peminjaman sarana prasarana di bumi perkemahan Kwartir Daerah Lampung masih dilakukan dengan cara manual.

c. Belum adanya sistem informasi terkomputerisasi peminjaman sarana prasarana di bumi perkemahan Kwartir Daerah Lampung.

\subsection{Batasan Masalah}

Agar pembahasan ini tidak terlalu meluas, maka pada penelitian ini penulis memberikan batasan masalah yaitu:

a. Bumi perkemahan yang hanya di kelola oleh Kwartir Daerah Lampung berjumlah 4 bumi perkemahan di tahun 2019.

b. Aplikasi peminjaman bumi perkemahan hanya untuk di Provinsi Lampung. 
c. Peminjaman sarana dan prasarana yang di dalam bumi perkemahan di Kwartir Daerah Lampung.

d. Aplikasi bisa Login, Registrasi, melihat informasi tentang bumi perkemahan yang di kelolah oleh Kwartir Daerah Lampung.

e. Aplikasi dibatasi pada peminjaman sampai pengembalian sarana dan prasarana bumi perkemahan Kwartir Daerah Lampung.

f. Untuk sementara penelitian ini sampai tahapan desain.

\subsection{Rumusan Masalah}

Adapun rumusan masalah dalam penelitian ini, yaitu "Bagaimana merancang sistem informasi peminjaman sarana prasarana di Kwartir Lampung berbasis mobile?".

\subsection{Kerangka Pemikiran}

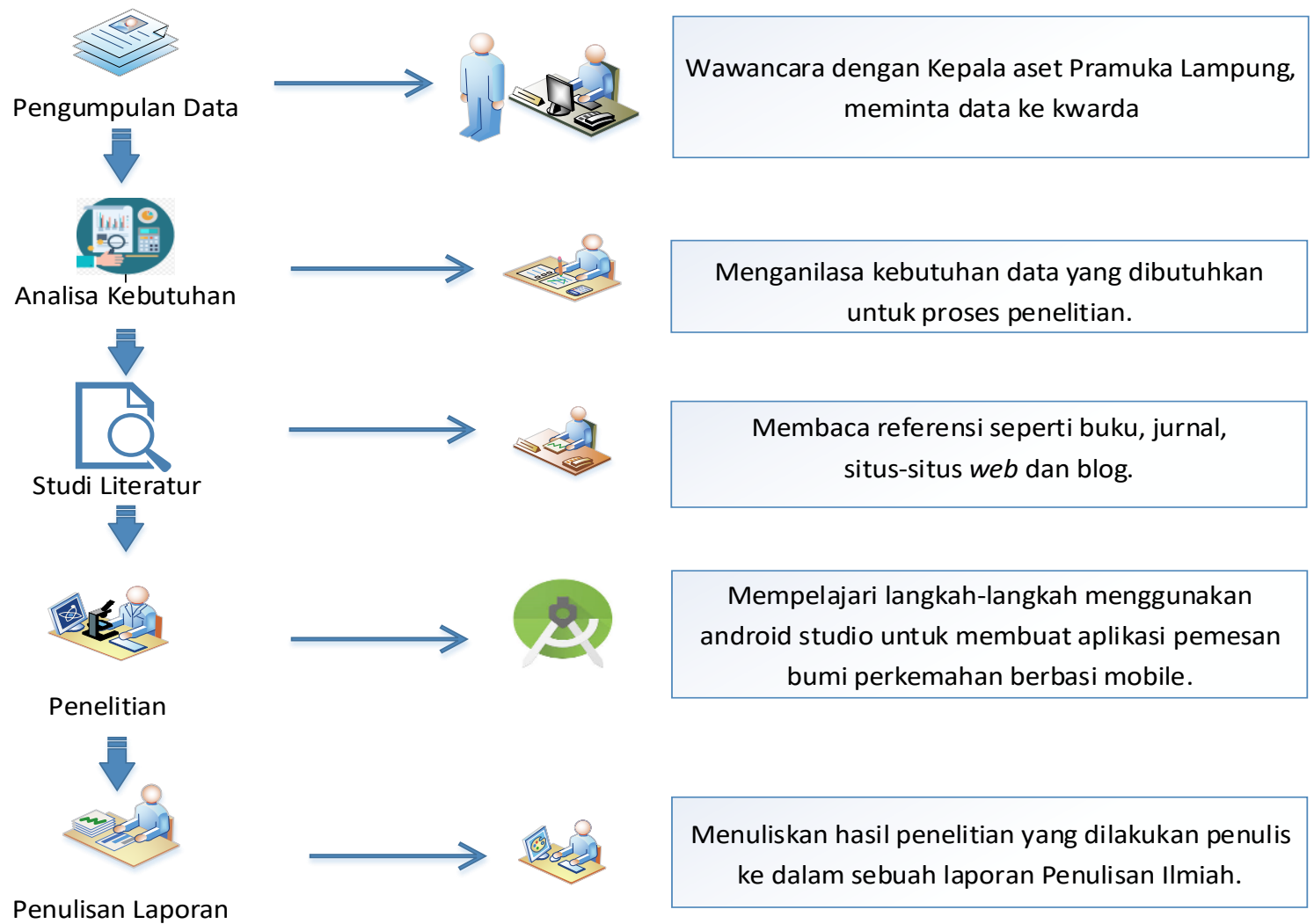

Gambar 1. Kerangka Pemikiran 


\subsection{Sistematika Penulisan}

Sistematika penulisan ini, menjelaskan secara singkat tentang susunan yang terdapat dalam penulisan ini. Penulisan ini terdiri dari 7 (Tujuh) poin, berikut uraian masing-masing setiap poin:

\section{PENDAHULUAN}

pada poin ini, menjelaskan tentang latar belakang masalah, identifikasi masalah, Batasan masalah, rumusan masalah, tujuan dan manfaat, kerangka pemikiran proposal penelitian ini serta sistematika penulisan.

\section{LANDASAN TEORI}

Pada poin ini, menjelaskan tentang berbagai macam referensi yang menjadi dalam penulisan, disertakan teori-teori pengenalan yang mengangkat tentang pendekatan yang digunakan.

\section{TUJUAN DAN MANFAAT PENELITIAN}

Merupakan poin yang menjelaskan pandangan mengenai berbagai macam tujuan dan manfaat dari penulisan ilmiah.

\section{METODE PENELITIAN}

Poin ini berisi tentang metode atau pendekatan maupun Teknik yang digunakan penulis dalam mengumpulkan data.

\section{HASIL ANALISIS DAN PEMBAHASAN}

Berisikan tentang semua hasil kajian yang telah dilakukan, proses implementasi dari sistem.

\section{RENCANA PENELITIAN BERIKUTNYA}

Pada poin ini menjelaskan tentang pengembangan atau perencanaan selanjutnya dari penulisan ilmiah yang kan dibuat di tugas akhir.

VII. KESIMPULAN DAN SARAN

Poin ini menjelaskan tentang kesimpulan dari penjelasan poin-poin sebelumnya, sehingga dari kesimpulan penulis mencoba memberi saran yang berguna untuk pengembangan apilkasi yang dibuat ini sesuai kebutuhan penggunanya.

\section{DAFTAR PUSTAKA}

\section{LAMPIRAN}




\section{LANDASAN TEORI}

\subsection{Tinjauan Pustaka}

Dari penelitian yang dilakukan, beberapa jurnal terkait dan beberapa penelitian yang menjadi referensi untuk dapat melakukan analisis dari beberapa tinjauan studi yaitu:

a. Sistem Pemesanan Lapangan Futsal Berasis Android (Ngabdilah, 2017).

Dengan perkembangan pengetahuan dan teknologi yang begitu pesat membuat semakin ketatnya persaingan dalam bidang bisnis, persaingan yang ketat antara pebisnis membuat setiap pebisnis meningkatkan performa dari bisnis yang mereka jalani. Untuk meningkatkan performa dari bisnis yang di jalani, maka di butuhkan sebuah sistem informasi yang handal dalam menjalankan bisnis tersebut. Salah satu bisnis yang membutuhkan sistem informasi dalam pengelolaan data informasinya yaitu bisnis penyewaan lapangan futsal. Maka dari itu untuk membangun sistem ini, metode yang digunakan adalah model Waterfall. Sistem yang digunakan perusahaan saat ini masih menggunakan sistem berbasis WEB. Kesimpulan hasil penelitian ini adalah telah tercipta sebuah sistem pemesanan lapangan futsal berbasis android yang dapat dijadikan sebagai solusi dalam menyelesaikan permasalahan dalam pemesanan lapangan futsal. Berdasarkan simpulan hasil penelitian ini, direkomendasikan: (1) Sistem pemesanan lapangan futsal berbasis android yang dibangun ini sangat membantu konsumen untuk melakukan proses pemesanan. (2) Dengan adanya sistem pemesanan lapangan futsal berbasis android ini, konsumen bisa pesan lapangan tanpa harus datang ketempat tersebut. (3) Dapat memberikan informasi jadwal mainnya dengan mudah.

b. Pembangunan Perangkat Lunak Penentuan Lokasi Perkemahan dan Penyewaan Alat Kemah Mengunakan Platform Andorid (Suhenda \& Hirawan, 2018).

Camping merupakan salah satu kegiatan outdoor yang banyak diminati di kalangan masyarakat. Namun, dalam melakukan kegiatan ini tidak jarang beberapa masyarakat merasa kesulitan dalam mencari dan memilih lokasi camping, tempat penyewaan alat camping, dan juga event-event camping. Berdasarkan masalah yang 
ada, maka di bangun sebuah perangkat lunak dengan tujuan dapat membantu dalam mencari tepat penyewaan peralatan camping. Adapun platform yang digunakan sebagai pilot project perangkat lunak ini Android. Hasilnya adalah perangkat lunak pemilihan lokasi perkemahan dan penyewaan alat kemah di Platform Android ini sudah membantu masyarakat dalam mencari dan memilih tempat camping dan untuk mencari penyewaan alat camping, perangkat lunak pemilihan lokasi perkemahan dan penyewaan alat kemah di Platform Android ini sudah membantu masyarakat untuk mencari informasi event-event camping.

c. Perancangan Aplikasi Penyewaan Sarana dan Prasarana di Sekolah Menengah Kejuruan Negeri 3 Garut (Bastaman , 2015).

Proses pendataan secara manual adalah kendala yang terjadi di sekolah ini. Keamanan, waktu, keefisiensian, kerapihan tata tulis, dan apabila kita berbicara kepada zaman sekarang rasanya sudah ketinggalan zaman apabila proses pendataan di sekolah ini masih menggunakan pendataan dengan cara tersebut. Maka, dilakukan perancangan sebuah aplikasi sarana dan prasarana Sekolah berbasis desktop. Metode pengembangan sistem yang digunakan dalam lapangan kerja praktek ini merupakan metodologi berorientasi objek yaitu Unified Approach (UA) dengan menggunakan Unified Modeling language (UML) untuk memodelkan kebutuhan sistem. Sistem yang dirancang dapat mengakomodasi kebutuhan dalam mempermudah dan mempercepat kinerja staf yang bertugas dalam mengelola data penyewaan Sarana dan Prasarana. Dengan demikian penyimpanan data-data tentang Sarana dan Prasarana pada current system dapat diminimalkan.

\subsection{Tinjauan Studi}

\subsubsection{Pengertian Analisis}

Analisis adalah aktivitas yang memuat sejumlah kegiatan seperti mengurai, membedakan, memilah sesuatu untuk digolongkan dan dikelompokkan kembali menurut kriteria tertentu, kemudian dicari kaitannya dan ditafsirkan maknanya. Dalam pengertian yang lain analisis adalah sikap atau perhatian terhadap sesuatu (benda, fakta, fenomena) sampai mampu menguraikan menjadi bagian-bagian, serta 
mengenal antarbagian tersebut dalam keseluruhan. Analisis dapat juga diartikan sebagai kemampuan memecahkan atau menguraikan suatu materi atau informasi menjadi komponen-komponen yang lebih kecil sehingga lebih mudah dipahami. Jadi, dari berbagai pengertian diatas dapat disimpulkan bahwa analisis adalah sekumpulan aktivitas dan proses. Salah satu bentuk analisis adalah merangkum sejumlah besar data yang masih mentah menjadi informasi yang dapat diinterpretasikan (pengertianahli.id, 2019).

\subsubsection{Pengertian Sistem}

Sistem merupakan sekumpulan elemen-elemen yang saling teritegrasi serta melaksanakan fungsinya masing-masing untuk mencapai tujuan yang telah ditetapkan. Karakteristik sistem terdiri dari: (Syahputra, 2014, pp. 11-12)

a. Komponen Sistem

b. Suatu sistem terdiri dari sejumlah komponen yang salig berinteraksi, yang artinya saling bekerja sama membentuk suatu kesatuan. Komponenkomponen sistem atau elemen-elemen sistem dapat berupa suatu subsistem atau bagian-bagian dari sistem.

c. Batasan Sistem

d. Batasan merupakan daerah yang membatasi anatar suatu sistem dengan sistem yang lainnya atau dengan luarnya. Batasan suatu sistem menunjukkan ruang lingkup sistem tersebut.

e. Lingkungan Luar Sistem

f. Lingkungan luar dari sistem adalah diluar batas dari sistem yang mempengaruhi operasi sistem.

g. Penghubung Sistem

h. Penghubung merupakan media penghubung antara satu subsistem dengan subsistem lainnya. Melalui penghubung ini memungkinkan sumber-sumber daya mengalir dari satu subsistem ke subsistem lainnya.

i. Masukan Sistem

j. Masukan sistem adalah energi yang dimasukan kedalam sistem. Masukan dapat berupa masukan perwatan (maintance input) dan masukan sinyal (signal input). 
k. Keluaran Sistem

1. Keluaran sistem adalah hasil energi yang diolah dan diklasifikasikn menjadi keluaran yang berguna dan sisa pembuangan.

m. Pengolah Sistem

n. Suatu sistem dapat mempunyai suatu bagian pengolah atau sistem itu sendiri sabagai pengolahnya. Pengolah akan mengubah masukan menjadi keluaran.

o. Sasaran Sistem

p. Suatu sistem mempunyai tujuan (goal) atau sasaran (objective).

\subsubsection{Pengertian Informasi}

Sekumpulan data / fakta yang diorganisasikan atau diolah dengan cara tertentu sehingga mempunyai arti bagi penerima. Data yang telah diolah menjadi sesuatu yang berguna bagi si penerima, maksudnya yaitu dapat memberikan keterangan atau pengetahuan. Dengan demikian yang menjadi sumber informasi adalah data (temukanpengertian.com, 2019).

\subsubsection{Android}

Pengertian Android adalah sebuah sistem operasi khusus yang dirancang untuk perangkat mobile layar sentuh atau disebut dengan smartphone. Sistem operasi ini merupakan pengembangan dari sistem operasi Linux yang sudah terbukti ketangguhan dan kehandalannya.

Sistem operasi Android mulai dikembangkan pada tahun 2003 oleh 4 pakar teknologi bernama Andy Rubin, Rich Miner, Nick Sears dan Chris White. Pada tanggal 17 Agustus 2005 perusahaan Google berhasil mengakuisisi Android, Inc sebagai anak perusahaannya. Walaupun Android sudah diakuisisi Google, pendiri perusahaan Android masih berperan penuh terhadap pengembangan OS ini.

\subsubsection{Pengertian Aplikasi Android}

Menurutnya, dalam aplikasi android menyediakan platform secara terbuka bagi para pengguna, pengembang dalam menciptakan berbagai bentuk aplikasi yang 
mereka inginkan. Apalikasi ini bisa dalam bentuk pengetahuan, game, pendidikan, agama, dan lain sebaginya. (Murtiwiyati \& Glenn , 2013)

Aplikasi Android menggunakan bahasa java, hal ini dapat mengontrol perangkat mobile melalui goole-enabled java. Ini adalah platform penting untuk mengembangkan aplikasi mobile menggunakan software stack yang disediakan di google Android SDK. Mobile Android OS menyediakan lingkungan yang fleksibel untuk pengembang aplikasi android yaitu bisa menggunakan Android java namun juga dapat menggunakan normal Java IDEs (Holla \& Mahima, 2012)

Menurutnya, aplikasi android telah diinstal lebih dari 10 milyar kali dan mencakup berbagai macam ketegori mulai dari games dan hiburan hingga layanan bisnis. Kesemua kategori ini miliki penghasilan tertentu yang biasanya di dapatkan dari google adsen. (Bhardwaj, 2013)

\subsubsection{Perkembangan Android}

Android merupakan "Open Mobile Platform" yang dikembangkan oleh Google, secara sederhana Android merupakan sebuah sistem operasi untuk handphone, seperti halnya Symbian atau Windows Phone. Android dikembangkan dari Sistem Operasi Linux, middleware, dan semua Aplikasinya dibuat dengan menggunakan Java. Perlengkapan penyediaan fitur dalam Android disertakan Standart Development Kit (SDK) dan pengembangan aplikasi dalam platform android disertakan Application Programming Interface (API) (Safaat, 2012).

Android berperan besar dalam perkembangan teknologi selama lebih dari enam tahun terakhir ini. Selama ini, banyak sekali orang telah dimanjakan oleh berbagai kemudahan yang diberikan oleh OS Android. Setelah Android muncul dan diakuisisi oleh Google, perusahaan ini kian fokus untuk berperang dalam kategori smartphone dan terus memberikan update terhadap sistem operasi yang diusungnya tersebut. Sejak diakuisisi oleh Google dan diterapkan ke dalam sebuah perangkat, OS Android dikembangkan dengan kode yang dinamai berdasarkan nama dessert (pencuci mulut) dan diurut berdasarkan alfabet, seperti 
Cupcake (OS Android 1.5), Donut (OS Android 1.6), Eclair (OS Android 2.0 2.1), Froyo (OS Android 2.2 - 2.2.3), Gingerbread (OS Android 2.3-2.3.7), Honeycomb (OS Android 3.0-3.2.6), Ice Cream Sandwich (OS Android 4.0 4.0.4), Jelly Bean (OS Android 4.1-4.3), KitKat (OS Android 4.4+) dan Lolipop (Android 5.+) merupakan versi selanjutnya, versi android ini sempat menjadi sangat viral dikalangan netizen dunia karena nama dari versi ini yang sangat dirahasiakan oleh pihak google.

Banyak nama spekulasi yang lahir dari berbagai kalangan, bahkan tak sedikit pula yang mengatakan bahwa Google akan menyudahi nama-nama makanan untuk versi android ini. Namun pada akhirnya, Google mengeluarkan nama resmi untuk android versi ini. Sesuai degan namanya, tampilan dari Android lolipop ini pun terlihat manis dan lebih simpel dari pendahulunya.

\subsubsection{Android Studio}

Android Studio adalah IDE pemrograman Android resmi dari Google yang dikembangkan dari IntelliJ. Sebelum ada Android Studio, programmer Android telah menggunakan Eclipse. Eclipse adalah IDE pemrograman Android sebelum munculnya Android Studio. Bisa dibilang Google telah berpaling dari Eclipse dan menjadikan Android Studio sebagai IDE resminya. Dikarenakan sudah meresmikan Android Studio pada tanggal 16 Mei 2013, Google menghentikan support ADT ke Eclipse tak lama kemudian dan ADT resmi hanya didapatkan oleh Android Studio.

Dikembangkan di atas IntelliJ IDEA besutan JetBrains, Android Studio dirancang khusus untuk pengembangan Android. IDE Ini tersedia untuk digunakan pada sistem operasi Windows, Mac OS X dan Linux. Android Studio dipilih karena memiliki banyak fitur yang memudahkan para pembuat program terutama programmer level dasar yang ingin belajar lebih tentang android. 


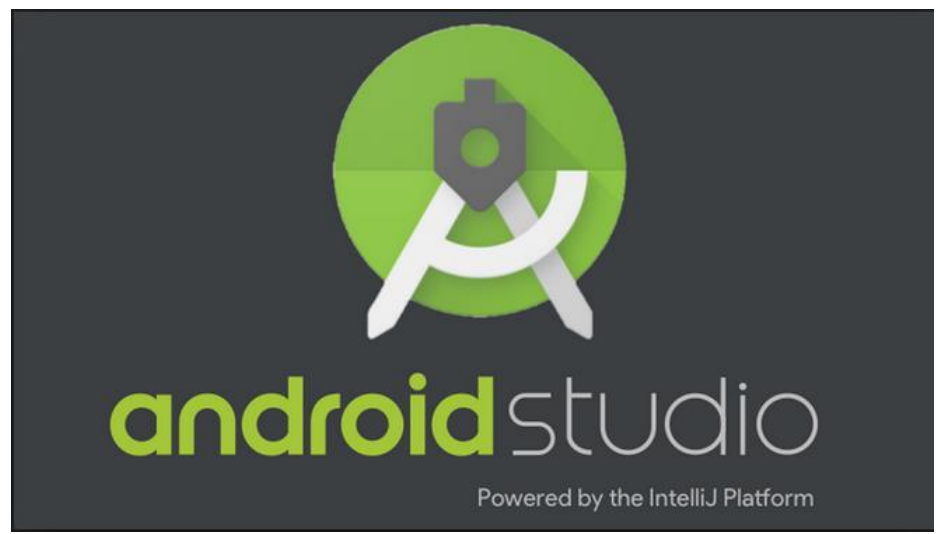

Gambar 2. Android Studio

\subsubsection{MongoDB}

MongoDB adalah salah satu produk Database NoSQl Open Source yang menggunakan struktur data JSON untuk menyimpan datanya. MongoDB merupakan database NoSQL paling popular di internet. MongoDB sering dipakai untuk aplikasi berbasis Cloud, Grid Compputing, atau Big Data (Saputra, 2019).

\subsubsection{Database NoSQL}

Database NoSQL adalah database yang tidak menggunkan realasi antar table dan tidak menyimpan data dalam format table kaku (kolom yang fix) seperti layaknya Relasional Database. Secara umum, database NoSQL dibagi menurut format penyimpanan dokumentnya. Berikut ini adalah pengelompokan database NoSQL berdasarkan model (Penyimpanan) datanya.

a. Document Database contohnya MongoDB, setiap satu object data tersimpan dalam satu dokumen. Document sendiri bisa terdiri dari key-value, dan value sendiri bisa berupa array atau key-value bertingkat.

b. Graph, format penyimpanan data dalam struktur graph. Format ini sering dipakai untuk data yang saling berhubungan seperti jejaring social.

c. Key - Value, contoh database jenis ini adalah Apache Cassandra.

d. Object Database. Format database yang disimpan dalam object-object, object disini sama dengan pengertian object di Pemograman berorientasi object.

e. Tipe lainya adalah Tabular, tuple store dan jenis lainnya. (Putra, 2019). 


\subsubsection{Postman}

Postman merupakan salah satu penyedia lingkungan pengembangan antarmuka pemrograman aplikasi yang cukup populer. Dengan menggunakan tools dari provider ini, para Developer dapat membangun dan menguji antarmuka pemrograman dengan lebih mudah. Fungsi dari postman sendiri adalah untuk menjalankan API, yang dimana API atau antarmuka pemrograman aplikasi merupakan salah satu hal yang cukup membantu dalam pengembangan sistem yang membutuhkan integrasi. Para pengembang dapat mengembangkan sistem dengan lebih mudah, karena di dalam sebuah API bisa memuat berbagai macam hal seperti fungsi, protokol, maupun tools.

\subsubsection{PhpStrom}

Postman merupakan salah satu penyedia lingkungan pengembangan antarmuka pemrograman aplikasi yang cukup populer. Dengan menggunakan tools dari provider ini, para developer dapat membangun dan menguji antarmuka pemrograman dengan lebih mudah. Fungsi dari postman sendiri adalah untuk menjalankan API, yang dimana API atau antarmuka pemrograman aplikasi merupakan salah satu hal yang cukup membantu dalam pengembangan sistem yang membutuhkan integrasi. Para pengembang dapat mengembangkan sistem dengan lebih mudah, karena di dalam sebuah API bisa memuat berbagai macam hal seperti fungsi, protokol, maupun tools.

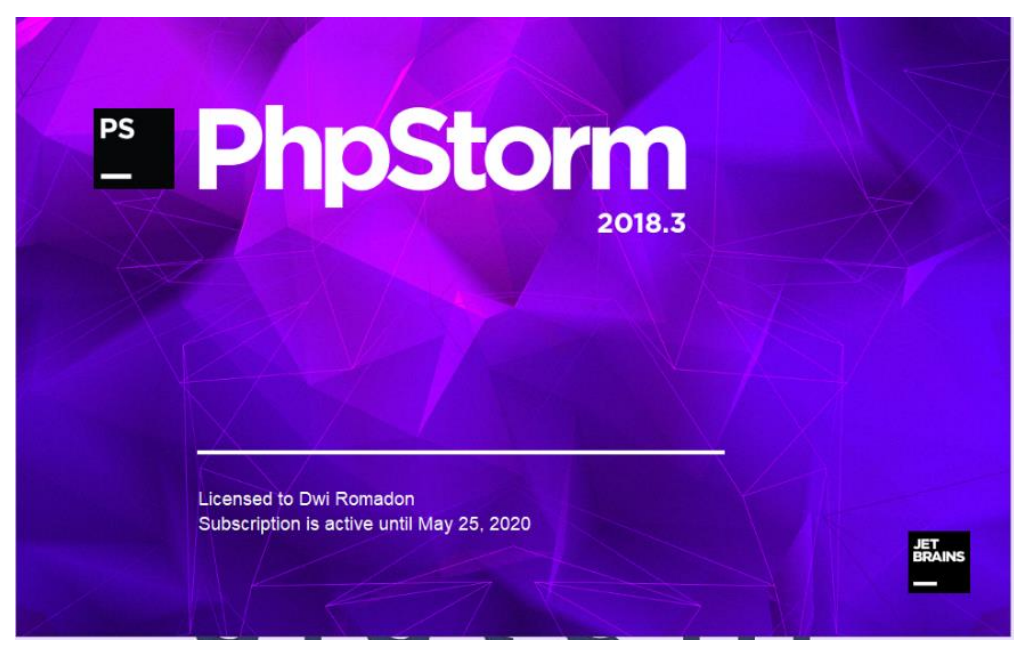

Gambar 3 PhpStrom 


\section{III.TUJUAN DAN MANFAAT}

\subsection{Tujuan Penelitian}

Adapun tujuan dari penelitian ini adalah:

a. Memberikan informasi mengenai lokasi sarana prasarana di bumi perkemahan yang ada di provinsi Lampung.

b. Proses peminjaman sarana prasarana di bumi perkemahan bisa dilakukan dimana saja dan kapan saja dengan sistem online.

c. Membuat aplikasi peminjaman sarana prasarana di bumi perkemahan berbasis mobile untuk di Provinsi Lampung.

\subsection{Manfaat Penelitian}

Adapun manfaat dari penelitian ini antara lain:

a. Dengan aplikasi peminjaman sarana prasarana di bumi perkemahan ini bisa mempermudah masyarakat dalam peminjaman dan mencari informasi tentang sarana prasarana di bumi perkemahan.

b. Dengan adanya aplikasi peminjaman ini masyarakat tidak perlu lagi datang ketempat tersebut untuk mengetahui sudah ada yang melakukan peminjaman apa belum.

c. Proses peminjaman sarana prasarana di bumi perkemahan bisa dilakukan lebih cepat.

d. Penelitian ini diharapkan bisa menjadi referensi bagi pengembang peminjaman sarana prasarana di bumi perkemahan.

e. Dengan adanya aplikasi peminjaman bumi perkemahan ini, diharapkan dapat meningkatkan kinerja pengelola bumi perkemahan di Provinsi Lampung secara efektif dan efesien. 


\section{METODE PENELITIAN}

\subsection{Analisis Kebutuhan}

Analisis kebutuhan adalah suatu proses untuk mendapatkan informasi, mode, spesifikasi tentang perangkat lunak yang diinginkan klien/pengguna. Kedua belah pihak, yaitu klien dan pembuat perangkat lunak terlibat aktif dalam tahap ini. Informasi dari klien yang akan menjadi acuan untuk melakukan desain perangkat lunak. Tahap ini dilakukan agar apa yang akan dibuat atau dirancang sesuai dengan kebutuhan sistem yang berdasarkan data-data pada tahap-tahap perancangan. Analisis kebutuhan perangkat keras dan perangkat lunak.

\subsection{Analisis Perangkat Keras (Hardware)}

Pada penelitian ini dibutuhkan beberapa komponen-komponen Hardware komputer sebagai berikut:

\begin{tabular}{|c|l|l|l|}
\hline No & \multicolumn{1}{|c|}{ Hardware } & \multicolumn{1}{c|}{ Laptop } & \multicolumn{1}{c|}{ Smartphone } \\
\hline 1 & Processor & Intel Celeron & Dual-Core $1.4 \mathrm{GHz}$ \\
\hline 2 & RAM & $4 \mathrm{~GB}$ & $2 \mathrm{~GB}$ \\
\hline 3 & Memory/Hardisk & $500 \mathrm{~GB}$ & $4 \mathrm{~GB}$ \\
\hline 4 & Layar & Resolution $1366 \times 768$ & 4.0 ( $(480 \times 800 \mathrm{pxl})$ \\
\hline 5 & Kabel USB & USB Type C & USB Type C \\
\hline
\end{tabular}

\subsection{Analisis Perangkat Lunak (Software)}

Pada penelitian ini Software yang digunakan oleh peneliti dalam melakukan penelitian

1) Android Studio V.3.4

2) ADB Driver Installer

3) PhpStrom

4) Windows 10

5) MongoDB 


\subsection{Metode Pengumpulan Data}

Pengumpulan data dilakukan untuk memperoleh informasi yang dibutuhkan dalam rangka mencapai tujuan penelitian. Metode pengumpulan data adalah Teknik atau cara yang dilakukan peneliti untuk mengumpulkan data.

Metode pengumpulan data yang digunakan diantaranya adalah:

a. Studi Literatur

Studi literatur adalah mencari referensi teori yang relefan dengan kasus atau permasalaha yang ditemukan. Referensi ini dapat dicari dari buku, jurnal, artikel laporan penelitian, dan situs-situs internet.

b. Wawancara

Wawancara adalah teknik pengumpulan data yang dilakukan melalui tatap muka dan tanya jawab langsung antara peneliti dan narasumber. Dalam penelitian ini penulis melakukan wawancara dengan Bpk. Sidik Purnomo selaku Manajer Gedung dan Bumi Perkemahan Kwarda Lampung di Kwarda Lampung. Dari wawancara yang dilakukan didapatlah hasil sebagai berikut:

Table 1. Bumi Perkemahan Provinsi Lampung

\begin{tabular}{|l|l|l|l|}
\hline $\begin{array}{l}\text { Pengelolah } \\
\text { Bumi } \\
\text { Perkemahan }\end{array}$ & Nama Bumi Perkemahan & $\begin{array}{l}\text { Luas dan } \\
\text { Kapasitas }\end{array}$ & $\begin{array}{l}\text { Jl. Pramuka } \\
\text { No.4 Rajabasa }\end{array}$ \\
\hline \multirow{5}{*}{$\begin{array}{l}\text { Kwarda } \\
\text { Lampung }\end{array}$} & Buperda Lampung & $\begin{array}{l}5 \text { hauntuk 1000 } \\
\text { orang }\end{array}$ & $\begin{array}{l}\text { Kota Bandar } \\
\text { Lampung. }\end{array}$ \\
\cline { 2 - 4 } & Buperda Tri Dharma Yoga & $\begin{array}{l}20 \text { ha untuk } \\
10.000 \text { orang }\end{array}$ & $\begin{array}{l}\text { Kecamatan } \\
\text { Ketapang }\end{array}$ \\
\cline { 2 - 4 } & Buperda Jati Agung & $\begin{array}{l}55 \text { ha untuk } \\
25.000 \text { orang }\end{array}$ & $\begin{array}{l}\text { Kab. Lampung } \\
\text { Selatan }\end{array}$ \\
\cline { 2 - 4 } Kwarcab Kota/ \\
Kabupaten & Buperda Rajabasa II & & $\begin{array}{l}\text { Desa Porwotani } \\
\text { Kec. Jati } \\
\text { Agung }\end{array}$ \\
\cline { 2 - 4 } & $\begin{array}{l}\text { Setiap Kwarcab memiliki } \\
\text { Buper dan jumlah Bupercab } \\
+/-15 \text { Buper. }\end{array}$ & & $\begin{array}{l}\text { Kab. Lampung } \\
\text { Selatan }\end{array}$ \\
\hline \multirow{3}{*}{ Swasta Lampung } & Buper Samar Scout & & $\begin{array}{l}\text { Kota Bandar } \\
\text { Lampung }\end{array}$ \\
\cline { 2 - 4 } & $\begin{array}{l}\text { Buper Wam Abdulahman } \\
\text { (Kehutanan) }\end{array}$ & & \\
\hline
\end{tabular}


Table 2 Fasilitas Buperda Lampung

\begin{tabular}{|c|c|c|c|c|c|}
\hline $\begin{array}{l}\text { Pengelolah } \\
\text { Bumi } \\
\text { Perkemahan }\end{array}$ & Fasilitas & Jumlah & Kapasitas & Kondisi & Lokasi \\
\hline \multirow[b]{2}{*}{ Aula } & $\begin{array}{l}\text { Aula Buperda } \\
\text { Pramuka }\end{array}$ & 2 buah & 1200 orang & Cukup Baik & $\begin{array}{l}\text { Kwarda } \\
\text { Lampung }\end{array}$ \\
\hline & Aula Jati Agung & 2 buah & 600 orang & Cukup Baik & $\begin{array}{l}\text { Desa } \\
\text { Porwotani } \\
\text { Kec. Jati } \\
\text { Agung } \\
\text { Kab. } \\
\text { Lampung } \\
\text { Selatan } \\
\end{array}$ \\
\hline \multirow{6}{*}{ Buperda } & Tapak Kemah & & & & \multirow{6}{*}{$\begin{array}{l}\text { Buperda } \\
\text { Lampung } \\
\text { Jl. } \\
\text { Pramuka } \\
\text { No.4 } \\
\text { Rajabasa }\end{array}$} \\
\hline & Mes/Penginapan & & & & \\
\hline & Tenda Regu & & 8 orang & Cukup Baik & \\
\hline & Tenda Kompi & & 20 orang & Cukup Baik & \\
\hline & Alat Kemah & & & & \\
\hline & Peralatan Outdoor & & & & \\
\hline
\end{tabular}

Table 3 Biaya Fasilitas Buperda Lampung

\begin{tabular}{|c|c|c|c|c|}
\hline \multirow[t]{2}{*}{ No } & \multirow[t]{2}{*}{ Uraian } & \multicolumn{2}{|c|}{ Tarif per Hari (Rp). } & \multirow[t]{2}{*}{ Keterangan } \\
\hline & & Umum & Pramuka & \\
\hline 1 & $\begin{array}{l}\text { Tapak Kemah } \\
\text { - } \quad \text { Hari Pertama } \\
\text { - } \quad \text { Hari Kedua dst }\end{array}$ & & & $\begin{array}{l}\text { Orangไhari } \\
\text { Orangไhari }\end{array}$ \\
\hline 2 & Mess & & & Kapst. 2 orang \\
\hline 3 & $\begin{array}{ll}\text { Gedung Pusdik } \\
-\quad \text { Hari Pertama } \\
-\quad \text { Hari Kedua dst } \\
\end{array}$ & & & \\
\hline 4 & Tenda Regu & & & Kapst. 8 orang \\
\hline 5 & Tenda KompilPasukan & & & Kapst. 20 orang \\
\hline 6 & $\begin{array}{ll}\text { Kursi. } \\
\text { - } & \text { Kursi VIPISofa } \\
\text { - } & \text { Kursi Stenlis + Cover } \\
- & \text { Kursi plastik + Cover }\end{array}$ & & & \\
\hline 7 & LCD Proyektor & & & Per harilevent \\
\hline 8 & Sound Sistem ruang besar & & & Per harilevent \\
\hline
\end{tabular}


Mekanisme Peminjaman Fasilitas di Kwarda Lampung

a. Calon pengguna mengajukan permohonan kepada Manajer Pengelolah Gedung dan Buper

b. Setelah di setujui calon pengguna baru bisa menggunakan fasilitas yang ada.

c. Pemesanan waktu (Booking Free) dikenakan biaya sebesar Rp. 500.000 (lima ratus ribu rupiah) dan tidak termask dalam paket sewa, kecuali melakukan pembayaran uang muka minimal 50\% dari nilai sewa.

d. Penggunaan gedung pada malam hari, hanya untuk hari Senin sampai dengan hari Kamis.

e. Pembayaran uang muka dilakukan 3 hari setelah pemesanan waktu atau selambat-lambatnya satu bulan sebelum pelaksanaan sebesar $50 \%$ dari nilai yang disepakati.

Kesimpulan dari wawancara dengan Bpk. Sidik Purnomo selaku Manajer Gedung dan Buper Kwarda Lampung dan Bpk. Johan selaku Penanggung Jawab Buper Jati Agung mereka menjelaskan kendala yang dialami oleh calon pengguna dalam melakukan peminjaman adalah belum adanya aplikasi peminjaman untuk Bumi Perkemahan dan juga karena jarak calon pengguna dengan lokasi Bumi Perkemahan cukup jauh. Karena, peminjaman masih dilakukan manual dengan langsung mendatangi pengelolah Bumi Perkemahan. Pengelolah Bumi Perkemahan juga belum menggunakan Sosial Media sebagai media informasi, sehingga belum banyak masyarakat yang mengetahui Bumi Perkemahan yang di Provinsi Lampung. Oleh karena itu, mereka sangat mendukung aplikasi yang akan penulis buat. 


\section{HASIL ANALISIS DAN PEMBAHASAN}

\subsection{Hasil Analisis}

Setelah melakukan penelitian, penulis akan menjabarkan hasil dan Analisis yang sudah dilakukan oleh penulis untuk perancangan aplikasi peminjaman Bumi Perkemahan untuk Provinsi Lampung menggunakan IDE Android Studio. Sistem ini memiliki admin yang mengelolah aplikasi dan user sebagai pengguna aplikasi.

\subsection{Kerangka Kerja Aplikasi}

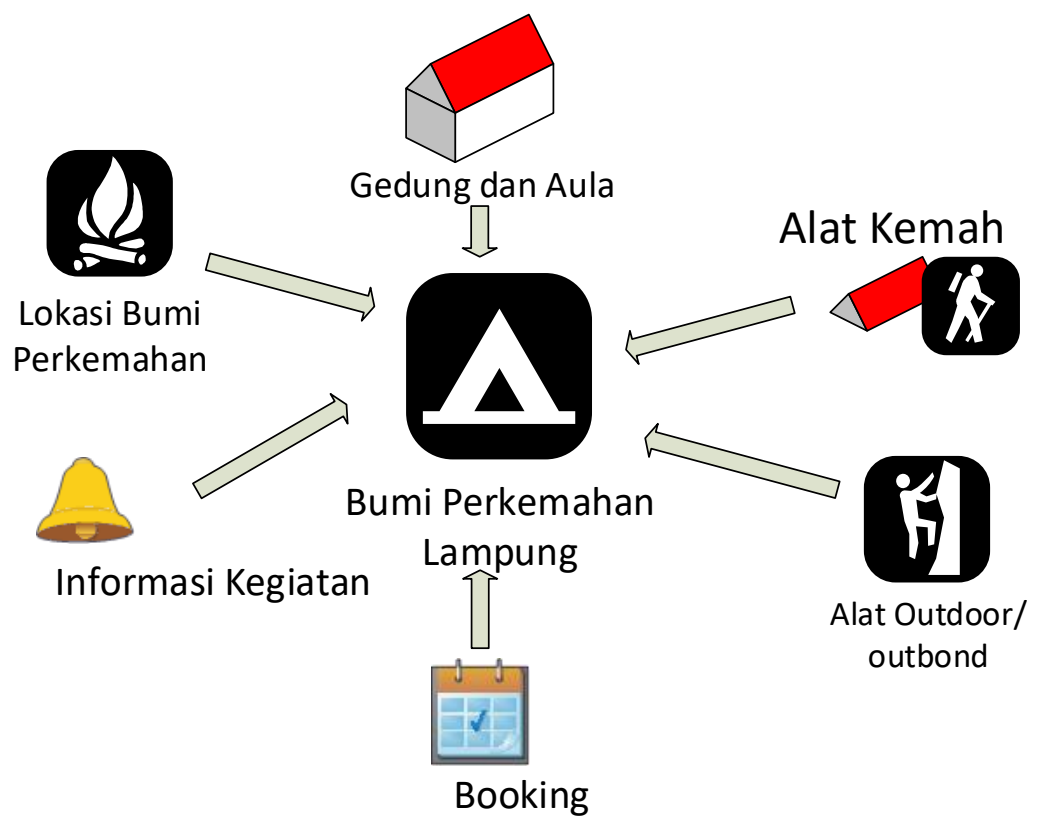

Gambar 4. Kerangka kerja Aplikasi

Aplikasi peminjaman Bumi Perkemahan Provinsi Lampung ini bertujuan untuk mempermudah masyarakat dalam lokasi dan alat kemah untuk berkemah. Dengan aplikasi ini dapat membantu masyarakat dalam mencari informasi tentang Bumi Perkemahan dan kemah sedangkan untuk pengelolah bumi perkemahan aplikasi ini bisa dalam hal promosi dan memperkenalkan Bumi Perkemahan kepada masyarakat luas. Aplikasi Bumi Perkemahan ini mempunyai beberapa fitur diantaranya, yaitu: 
a. Fitur Informasi Lokasi Bumi Perkemahan; Berisi tentang informasi Bumi Perkemahan yang ada di Provinsi Lampung.

b. Fitur Gedung dan Aula; Berisi tentang gedung dan aula yang ada di dalam bumi perkemahan yang biasa digunakan untuk pesta pernikahan dan Pendidikan dalam ruangan.

c. Fitur Alat Kemah; Berisi tentang perlengkapan untuk berkemah.

d. Fitur Alat Outdoor/Outbond; Berisi tentang perlengkapan untuk outbond.

e. Fitur Informasi Kegiatan; Berisi tentang informasi kegiatan yang ada di Bumi Perkemahan Provinsi Lampung.

f. Fitur Booking; Berisi tentang jadwal peminjaman Bumi Perkemahan dan Fasiltas yang ada.

\subsection{Use Case Diagram}

Secara garis besar, proses sistem yang akan dirancang digambarkan dengan Use Case Diagram sebagai berikut:

Peminjaman Bumi Perkemahan Di Provinsi Lampung

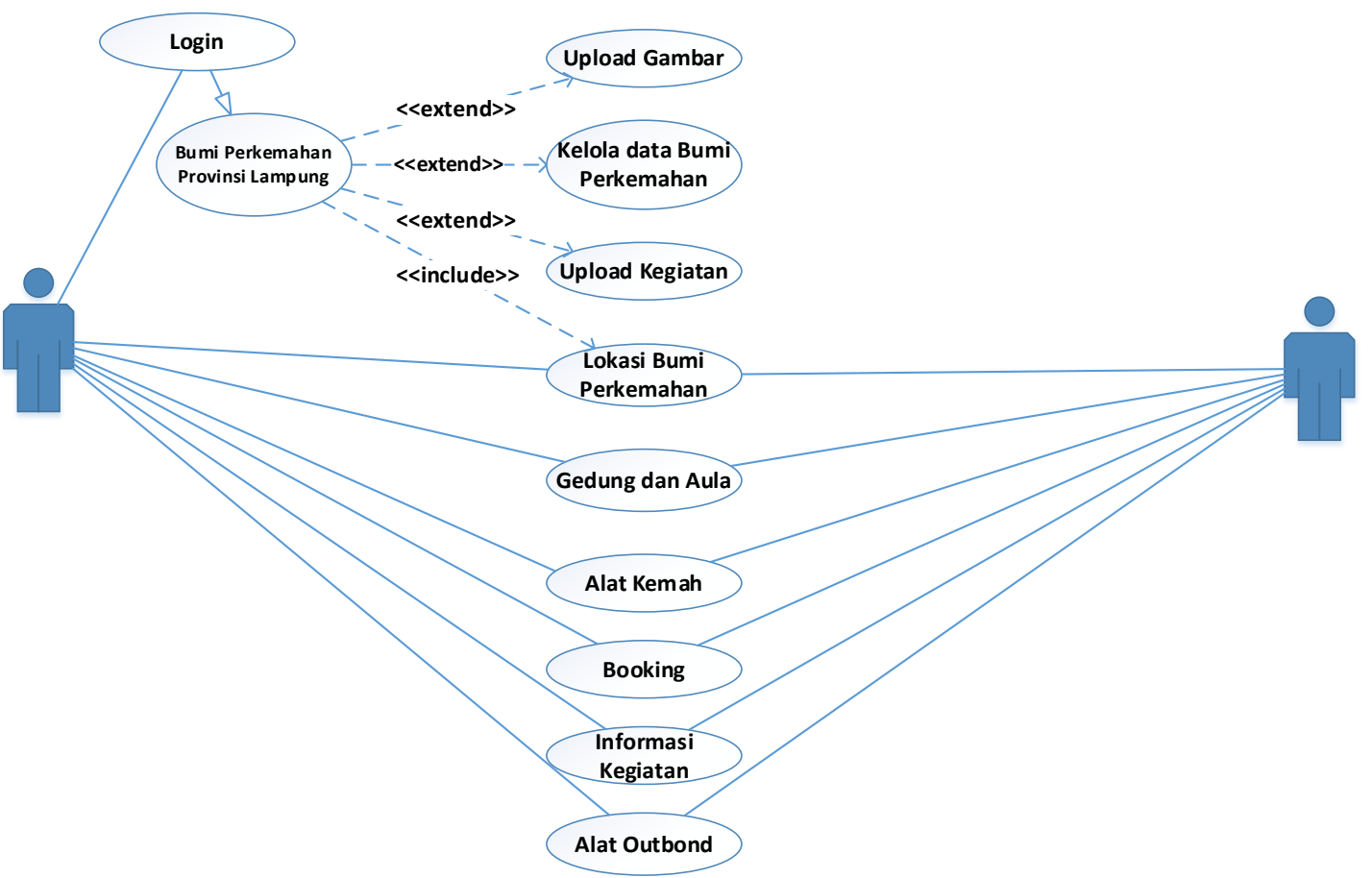

Gambar 5. Use Case Diagram 


\subsection{Langkah - Langkah Pembuatan Aplikasi}

\section{$5.5 \mathrm{API}$}

Sebelum membuat project di Android Studio, terlebih dahulu buatlah API menggunakan PhpStrom yang berfungsi menjembatani Database dan Andrid Studio. API berfungsi sebagai pembawa pesan yang menerima permintaan pengguna dan memberitahukan sistem apa yang harus sistem lakukan, kemudian memberikan respons yang sesuai untuk permintaan tersebut. Jika API sudah dibuat maka lakukan test menggunakan Postman dan lihat responnya apakah API berjalan atau tidak.

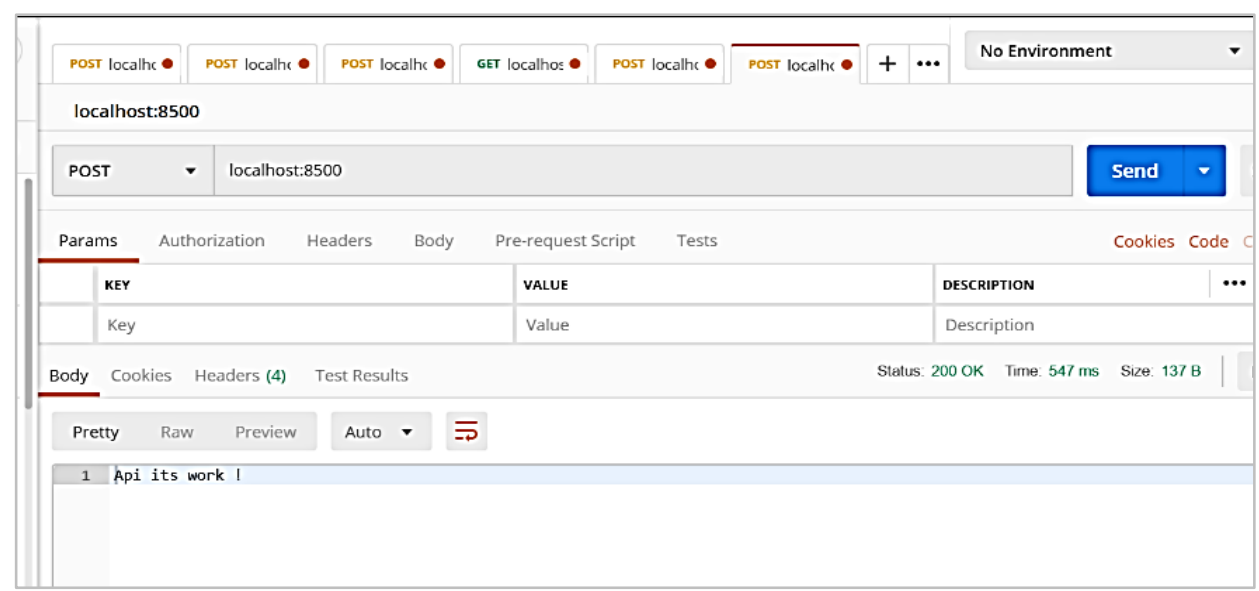

Gambar 6 API Its Work

\subsection{Android Studio}

Proses selanjutnya desain aplikasi di Android Studio. Buka Android Studio dan pilih start a new Android Studio project, akan muncul halaman seperti Gambar 7.

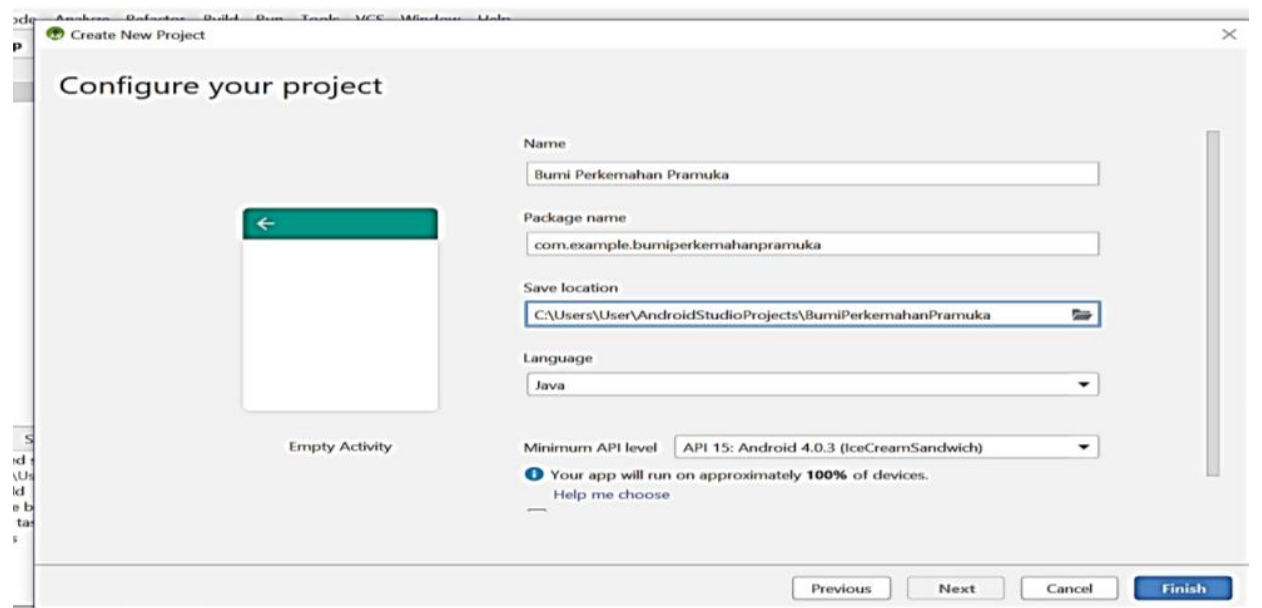

Gambar 7 Nama Project 
Setelah itu muncul pilihan activity seperti dibawah ini. Lalu pilih yang Empty Activity. Setelah itu, pilih next dan lalu pilih selesai.

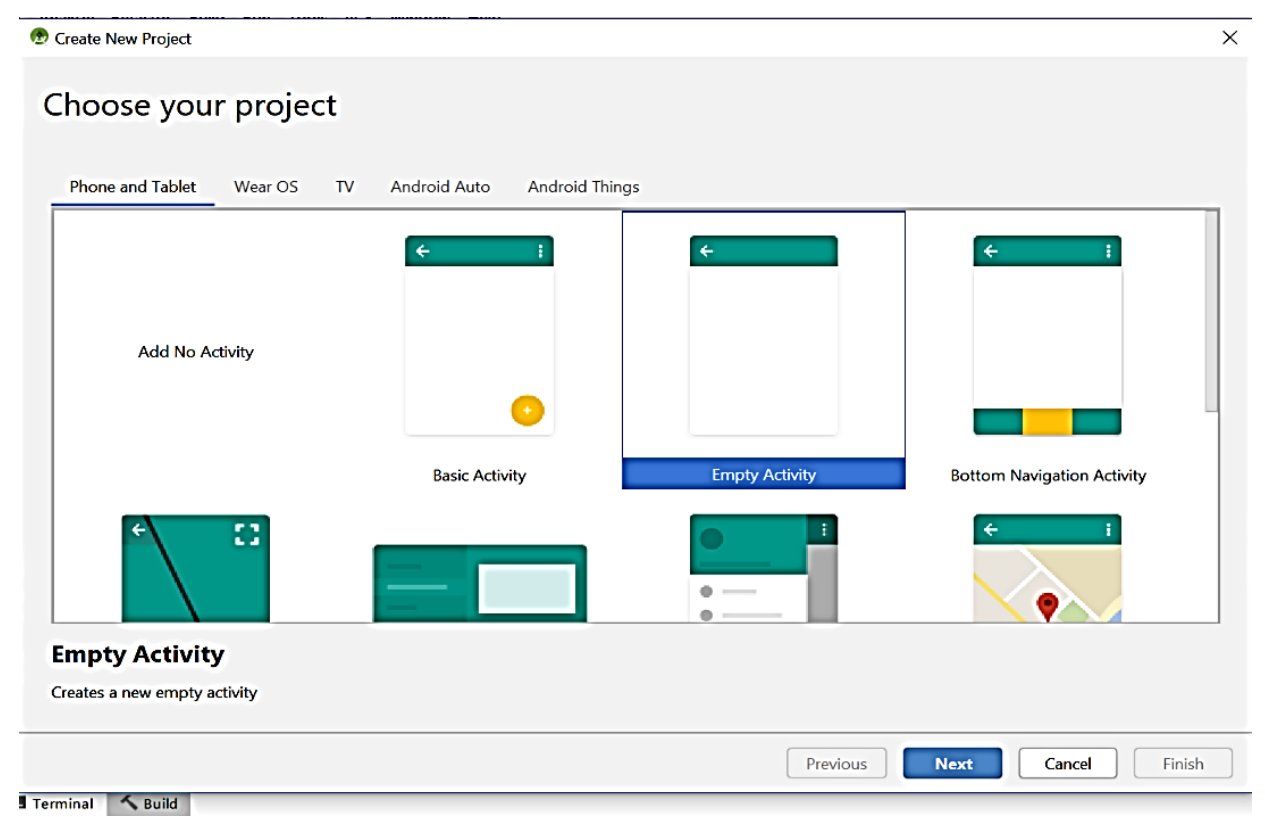

Gambar 8 Project Baru

Setelah itu, buat activity baru untuk memulai project. Seperti gambar dibawah ini. Begitupun selanjutnya untuk membuat activity yang lainnya sesuai kebutuhan.

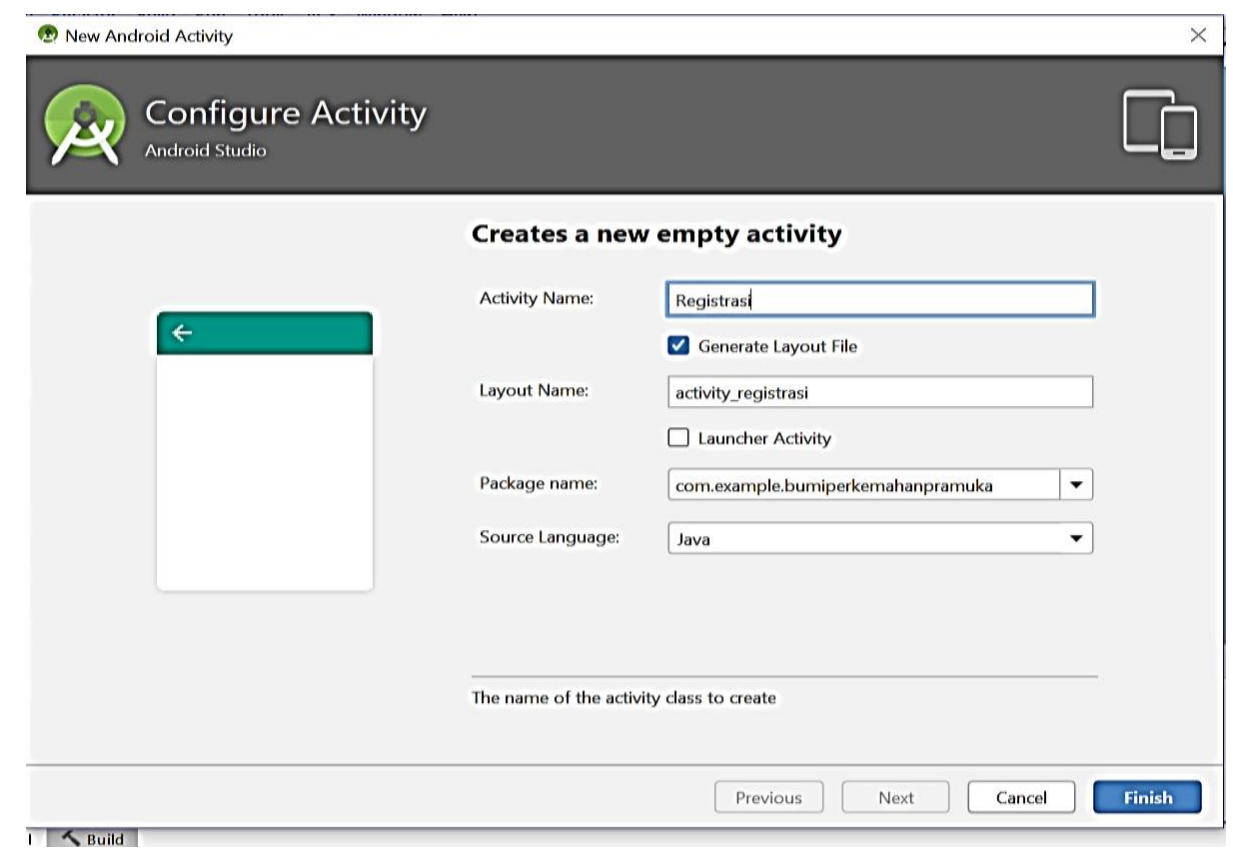

Gambar 9 Activity Registrasi 
Tampilan Environment Android Studio, setelah membuat activity baru.

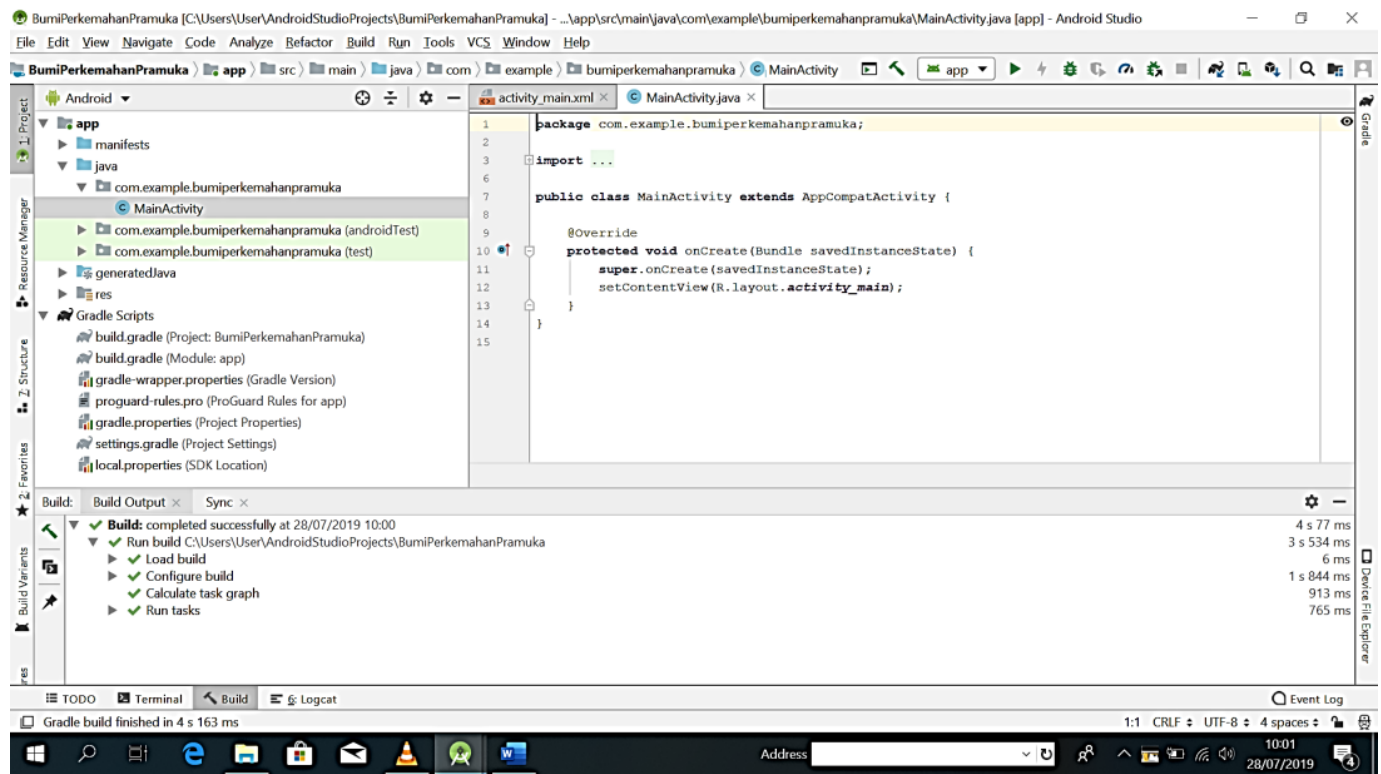

Gambar 10 Tampilan Enviroment

\subsection{Tampilan Aplikasi Bumi Perkemahan}

a. Tampilan Menu Login

Menu login berfungsi sebagai perintah utama memasuki atau menggunakan aplikasi. Di menu login diperuntukan untuk yang sudah memiliki akun, jika belum mempunyai akun anda bisa mendaftar terlebih dahulu melalui menu registrasi.

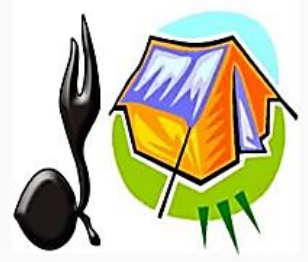

Sign In

$\square$ Email

Password

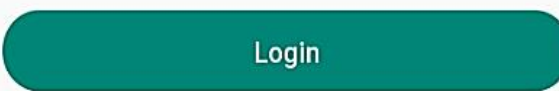

Belum punya akun? daftar disini

Gambar 11 Tampilan Menu Login 
b. Tampilan Menu Utama

Halaman menu utama berisikan halaman kontrol data informasi yang terdiri dari 6 sub menu, berisi tentang lokasi bumi perkemahan, fasilitas alat kemah, booking, dan informasi mengenai bumi perkemahan.

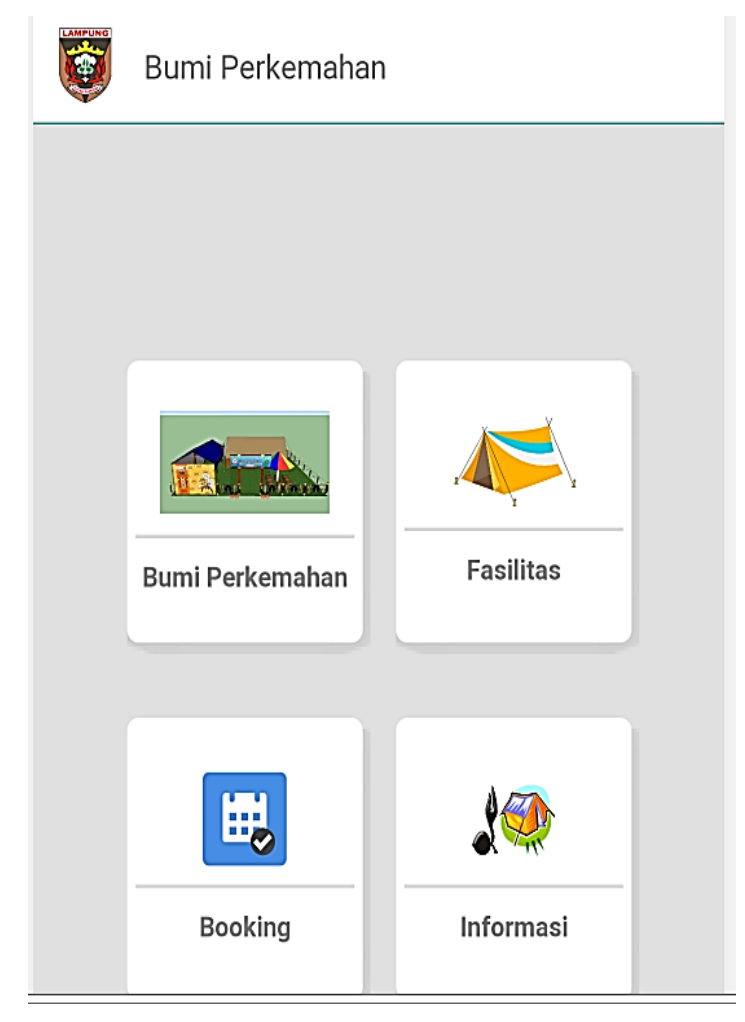

Gambar 12 Tampilan Menu Utama

Dari masing-masing menu diatas berikut penjelasannya:

1) Bumi perkemahan; Berisi tentang informasi bumi perkemahan yang ada di Kwartir Lampung.

2) Fasilitas; Berisi tentang informasi fasilitas alat kemah yang ada di bumi perkemahan Kwartir Lampung.

3) Booking; Berisi tentang jadwal peminjaman sarana prasaran bumi perkemahan di Kwartir Lampung.

4) Informasi; Berisi tentang informasi profil bumi perkemahan yang ada di Kwartir Lampung. 


\section{RENCANA PENELITIAN BERIKUTNYA}

Pada penelitian ini penulis hanya mengAnalisis bumi perkemahan yang di kelolah oleh kwarda lampung dan membuat desain nya di android studio. Untuk rencana penelitian selanjutnya yang akan peneliti lakukan adalah sebagai berikut:

a. Mengintergrasikan Bumi Perkemahan di Provinsi Lampung dalam satu aplikasi.

b. Melengkapi informasi terkait dengan Bumi Perkemahan yang di Provinsi Lampung.

c. Memberikan informasi yang real time dan terupdate mengenai kegiatan yang ada di Bumi Perkemahan tersebut. 


\section{KESIMPULAN DAN SARAN}

\subsection{Kesimpulan}

Berdasarkan hasil analisis pembahasan dengan menggunakan Android Studio untuk aplikasi peminjaman Bumi Perkemahan dapat disimpulkan:

a. Aplikasi ini diharapkan dapat membantu masyarakat dalam mencari informasi tentang lokasi bumi perkemahan di kwartir Lampung.

b. Aplikasi ini diharapkan bisa membantu masyarakat dalam proses peminjaman sarana prasarana bumi perkemahan di kwartir Lampung untuk kegiatan-kegiatan berkemah atau organisasi.

c. Dengan adanya aplikasi Peminjaman sarana prasarana bumi perkemahan berbasis mobile ini diharapkan bisa membantu masyarakat dalam mencari informasi tentang bumi perkemahan di kwartir Lampung.

\subsection{Saran}

Berdasarkan pembahasan, maka dari itu penulis menyarankan sebagai berikut:

a. Pada penelitian ini penulis hanya sampai tahapan desain, disarankan untuk membuat melanjutkan sampai pembuatan aplikasi yang di lengkapi fiturfitur yang dibutuhkan.

b. Melengkapi informasi tentang lokasi bumi perkemahan di kwartir Lampung.

c. Aplikasi ini dapat dimanfaatkan atau dikembangkan sesuai kebutuhan pengguna masing-masing. 


\section{DAFTAR PUSTAKA}

(2019, Agustus 5). Retrieved from pengertianahli.id:

https://pengertianahli.id/2014/08/pengertian-analisis-apa-itu-analisis.html

(2019, Agustus 6). Retrieved from temukanpengertian.com:

https://www.temukanpengertian.com/2013/07/pengertian-informasi.html

Bastaman , R. F. (2015). Perancangan Aplikasi Penyewaan Sarana dan Prasarana di Sekolah Menengah Kejuruan Negeri 3 Garut. Jurnal Algoritma.

Bhardwaj. (2013). 4 Pengertian Aplikasi Android Menurut Para Ahli dan

Penjelasan. Retrieved from www.indonesiastudents.com:

https://www.indonesiastudents.com/pengertian-aplakasi-android-menurutpara-ahli/

Erlangga, E., \& Dharmawan, Y. Y. (2017). Implemantasi Apps Teacher Kit untuk Proses Administrasi Dosen Mandiri yang Efektif, Efisien, dan Paperless. Explore: Jurnal Sistem Informasi dan Telematika (Telekomunikasi, Multimedia dan Informatika), 8(2).

Gorys, K. (n.d.). Pengertian Analisa Menurut Ahli| Pengertian dan Definisi.

Retrieved from pengertiandefinisi.com: https://pengertiandefinisi.com

Holla, \& Mahima. (2012). 4 Pengertian Aplikasi Android Menurut Para Ahli dan

Penjelasan. Retrieved from www.indonesiastudents.com:

https://www.indonesiastudents.com/pengertian-aplakasi-android-menurutpara-ahli/

Murtiwiyati, \& Glenn, L. (2013). 4 Pengertian Aplikasi Android Menurut Para

Ahli dan Penjelasan. Retrieved from www.indonesiastudents.com:

https://www.indonesiastudents.com/pengertian-aplakasi-android-menurutpara-ahli/

Ngabdilah, S. (2017). Sistem Pemesanan Lapangan Futsal Berbasis Android.

Artikel Skripsi Universitas Nusantara PGRI Kediri.

Prasetyo, A. D. (n.d.). APLIKASI MOBILE PENENTUAN LOKASI

PERKEMAHAN DI JAWA TIMUR BERBASIS ANDROID . 2. 
Putra, C. A. (2019, agustus 5). Pengantar Database NoSQL dan MongoDB. Retrieved from http://www.candra.web.id: http://www.candra.web.id/pengantar-database-nosql-dan-mongodb/

Robert, J. S. (1991). Pengertian Analisa Menurut Ahli| Pengertian dan Definisi. Retrieved from pengertiandefinisi.com: https://pengertiandefinisi.com/pengertian-analisa-menurut-ahli/

Safaat. (2012). Pemodelan Aplikasi Mobile Reminder Berbasis Android.

Retrieved from fti.uajy.ac.id:

https://fti.uajy.ac.id/sentika/publikasi/makalah/2016/38.pdf

Saputra, M. (2019, Agustus 6). Mengenal MongoDB Database NoSQL. Retrieved from http://developer.erabelajar.com:

http://developer.erabelajar.com/mengenal-mongodb-database-nosq1/

Suhenda, M. S., \& Hirawan, D. (2018). Pembangunan Perangkat Lunak Penentuan Lokasi Perkemahan dan Penyewaan Alat Kemah Menggunakan Platform Android. Jurnal Ilmiah Komputer dan Informatika (KOMPUTA), 1 .

Susanty, W., Thamrin, T., Erlangga, E., \& Cucus, A. (2012, June). Document management system based on paperless. In International Conference on Engineering and Technology Development (ICETD).

Syahputra, A. R. (2014). Sistem Informasi Geografis Tata Letak Perkemahan di Sumatera Utara. Sistem Informasi Geografis, 2.

Tri Senjaya, C. B. (2019, 08 28). Perkembangan dan kemajuan teknologi saat ini. Retrieved from http://cahbagus.student.umm.ac.id: http://cahbagus.student.umm.ac.id/2016/06/01/perkembangan-dankemajuan-teknologi-saat-ini/ 
LAMPIRAN 


\section{UL UNIVERSITAS BANDAR LAMPUNG FAKULTAS ILMU KOMPUTER}

Jl. ZA Pagar Alam No.89, Gedong Meneng, Rajabasa, Bandar Lampung. 35142. Telp:0721-701979, Fax:0721 -701467

\section{JADWAL KEGIATAN BIMBINGAN PENULISAN ILMIAH}

Nama

NPM : 16411021

: Wina Sagita

Program Studi : Sistem Informasi

Judul Penulisan : Analisis Sistem Informasi Peminjaman Sarara Proyarora Bumi Perkemahan KWartirLampung

Pembimbing : Erlangga, S.kom., M.kom

\begin{tabular}{|c|c|c|c|}
\hline Tanggal & $\begin{array}{c}\text { Bimbingan } \\
\text { ke }\end{array}$ & Perubahan/koreksi/isi materi & $\begin{array}{c}\text { Paraf } \\
\text { Pebimbing }\end{array}$ \\
\hline $19 / 06$ & 1 & 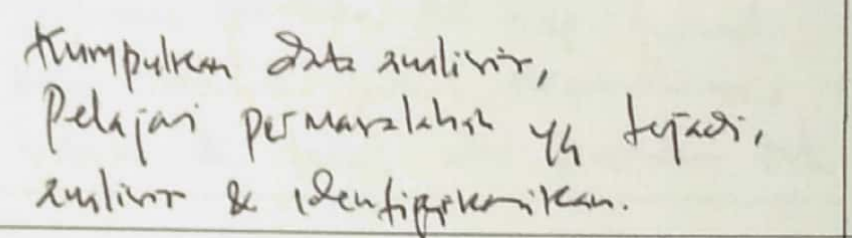 & \\
\hline & 2 & $\begin{array}{l}\text { Pelajen Kourep poneltian ini } \\
\text { apa k dapkimann? }\end{array}$ & \\
\hline $30 /$ row & 3 & 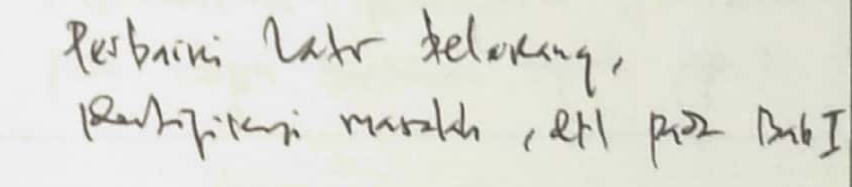 & \\
\hline 102 & 4 & 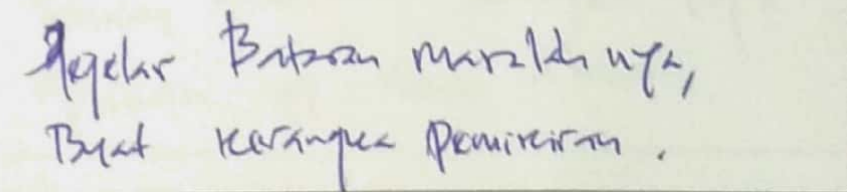 & \\
\hline
\end{tabular}

Bandar Lampung,

Dekan Fakultas Ilmu Komputer 


\section{USL UNVERESITAS BANDAR LAMPING J1. ZA Pagar Alam \\ 35142. Telp:0721-701979, Fax:072I -701467, Bandar Lampung.}

\section{JADWAL KEGIATAN BIMBINGAN PENULISAN ILMIAH}

Nama

NPM

: Wina Sagita

: 16411021

Program Studi : Sistem Informasi

Judul Penulisan : Analisis Sistem Informasi Peminjaman (Garame frotonana Bumi Perkemahan KWartikr Lampung

Pembimbing : Erlangga, S.kom., M.kom

\begin{tabular}{|c|c|c|c|}
\hline Tanggal & $\begin{array}{c}\text { Bimbingan } \\
\text { ke }\end{array}$ & Perubahan/koreksi/isi materi & $\begin{array}{c}\text { Paraf } \\
\text { Pebimbing }\end{array}$ \\
\hline $06 /$ mor & 5 & 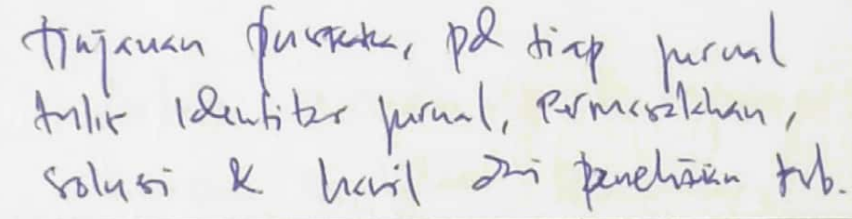 & \\
\hline $12 / 2084$ & 6 & 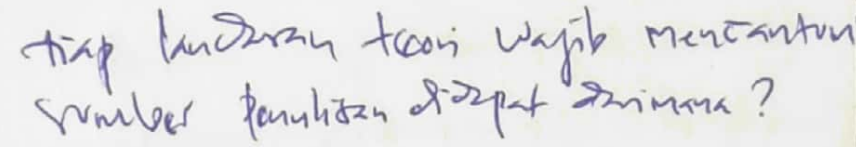 & \\
\hline$y_{0} \sin$ & 7 & 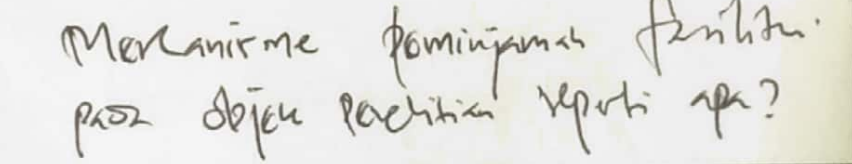 & \\
\hline $16 / 08$ & 8 & 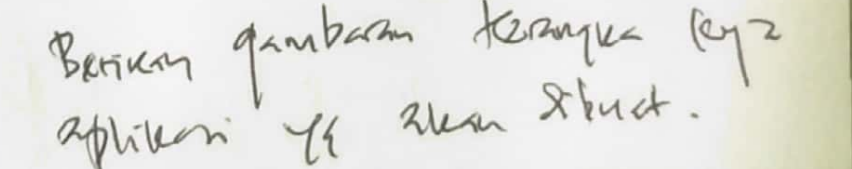 & \\
\hline
\end{tabular}

Bandar Lampung,

Dekan Fakultas Ilmu Komputer 
UL UNIVERSITAS BANDAR LAMPUNG FAKULTAS ILMU KOMPUTER

Jl. ZA Pagar Alam No.89, Gedong Meneng, Rajabasa, Bandar Lampung. 35142. Telp:0721-701979, Fax:0721 -701467

\section{JADWAL KEGIATAN BIMBINGAN PENULISAN ILMIAH}

Nama : Wina Sagita

NPM : 16411021

Program Studi : Sistem Informasi

Judul Penulisan : Analisis Sistem Informasi Peminjaman Sarara Prajarara Bumi Perkemahankuarite Lampung

Pembimbing : Erlangga, S.kom., M.kom

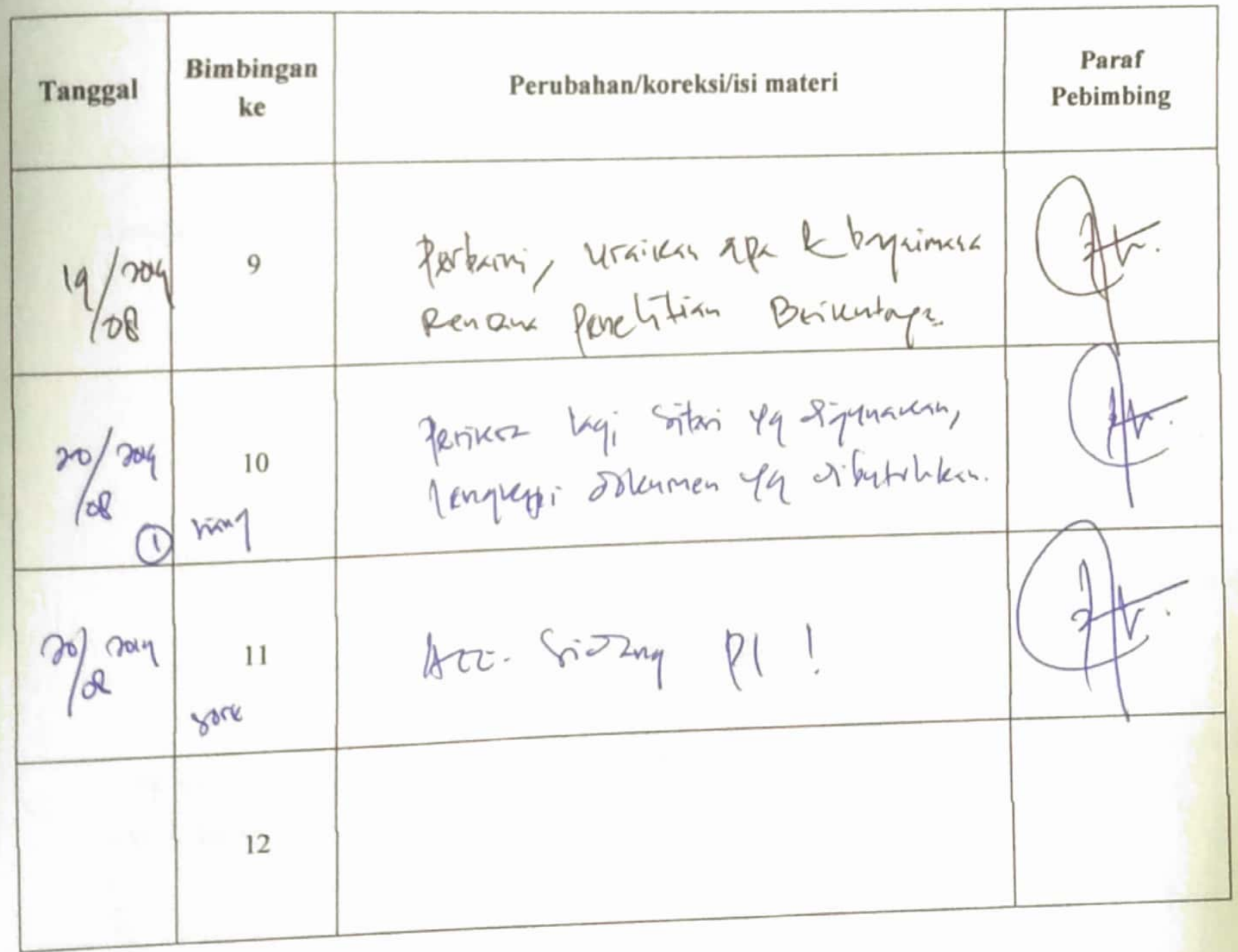

Bandar Lampung,

Dekan Fakultas Ilmu Komputer

Ahmad Cucus, S.Kom., M.Kom 
UNIVERSTTAS BANDAR LAMPUNG

FAKULTAS ILMU KOMPUTER

PROGRAM STUIDI SISTEMI INFORMASI

PERBAKAN PENULISAN

WINA SAGITH

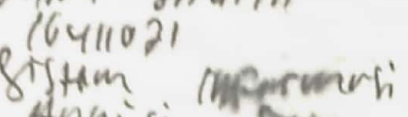

Anaisi fisterm laparmasi Penirnjaman sorann

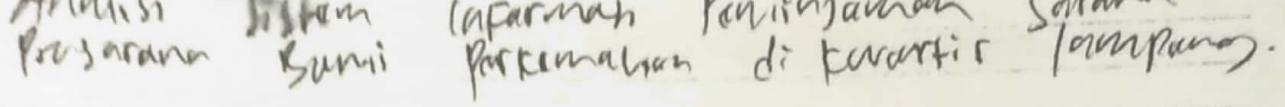

IIIIIPIVGI.II

Taquan

A. Cucus.

fenty

Yuths'

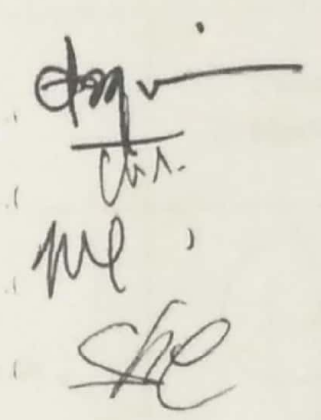

zudul Siganti:- Lesign \& perancangar.

- Analisa diganti dgn perancanga....

- Landason Teor, yg tdk berhubungan dqn judol dihapus.

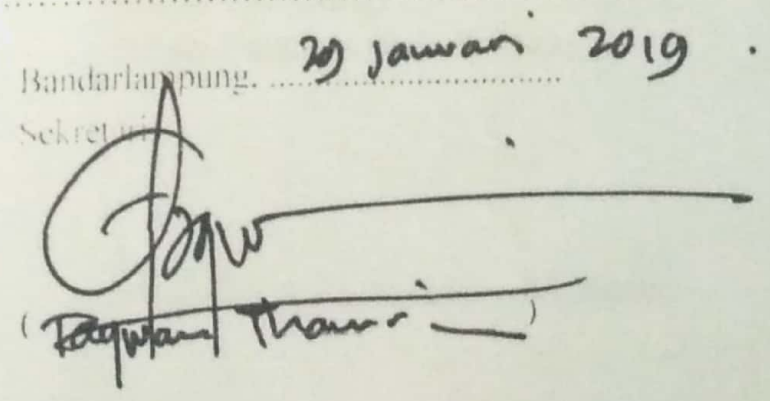


Berita Acara Cetak Soft Cover

$$
\begin{array}{ll}
\text { Nama } & : \text { WINA SAGITA } \\
\text { NPM } & : 16411021 \\
\text { Prodi } & : \text { Sistam informoy } \\
\text { Judul PI } & : \text { St }
\end{array}
$$

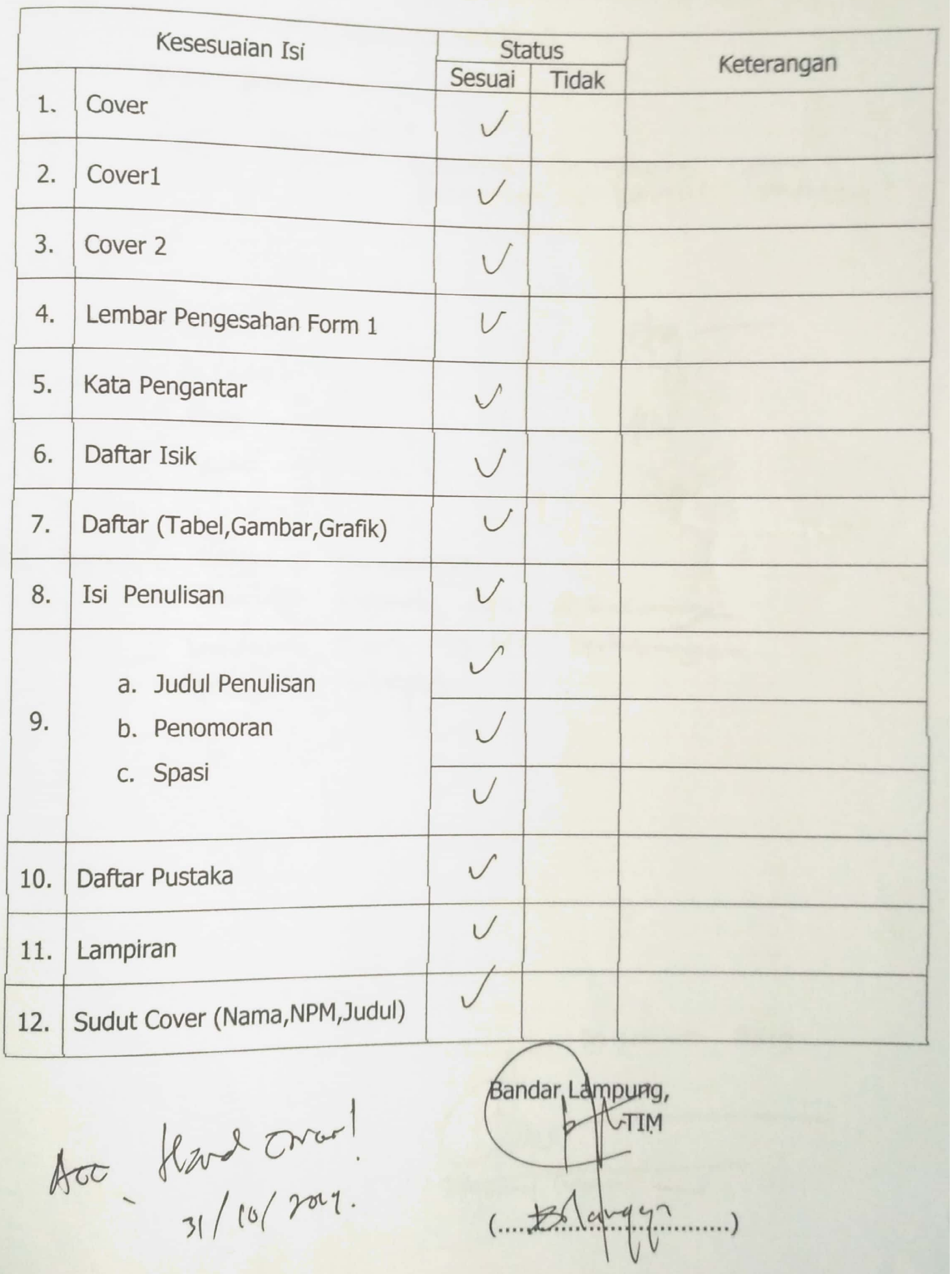




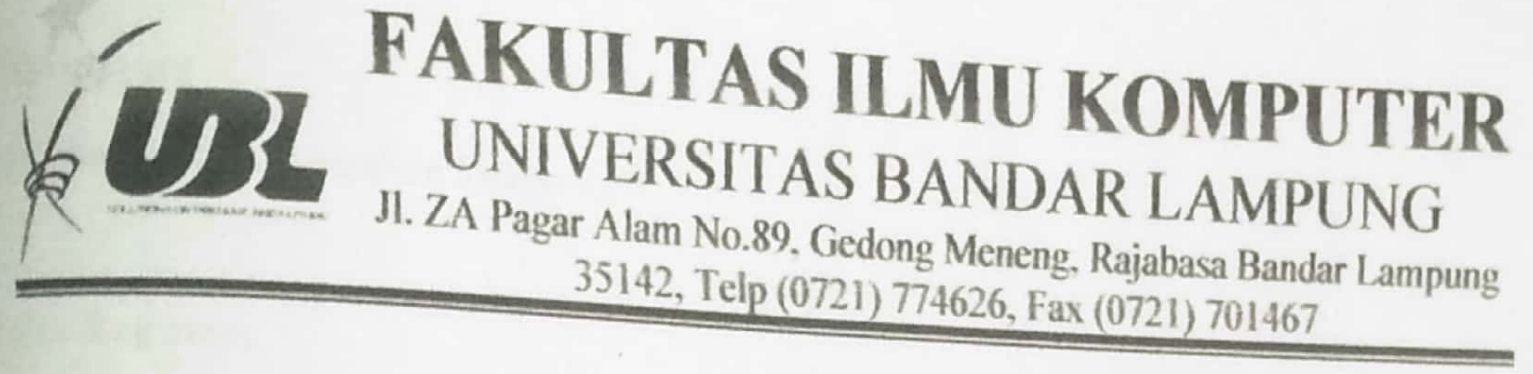

Bandar Lampung, 5 Juli 2019

Nomor : 124/FIK/SI/VII/2019

Lamp : -

Perihal: Permohonan ljin Penelitian

Kepada Yth,

Kepala Kwarda Lampung

$\mathrm{Di}-$

Lampung

Dengan Hormat,

Dengan ini kami menerangkan bahwa:

$\begin{array}{ll}\text { Nama } & \text { : Wina Sagita } \\ \text { Npm } & : 16411021 \\ \text { Fakultas } & : \text { Ilmu Komputer } \\ \text { Program Study: Sistem Informasi }\end{array}$

Adalah mahasiswa kami, akan mengadakan Penelitian dalam rangka menyusun Analis Data di Kwarda Lampung. Maka dengan ini kami memohon bantuan Bapak/lbu untuk memberikan izin melakukan riset (analisis data) di Kwarda Lampung.

Demikian harapan kami atas perhatian, bantuan dan kerja sama bapak dan ibu kami ucapkan terima kasih.

Ketua Program Studi

Sistem Informasi.

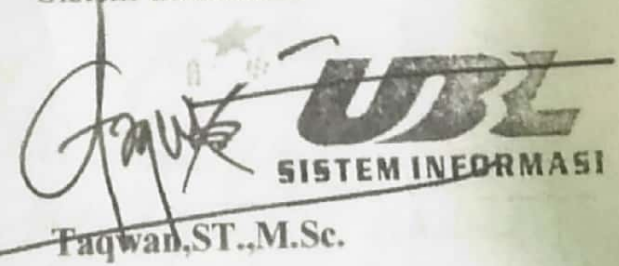


Topik Wawancara

"Peminjaman Bumi Perkemahan Lampung"

Waktu dan Kegiatan:

Acara ini dilaksanakan pada:

Hari/Tanggal : Rabu, 31 Juli 2019

Pukul : $10.00 \mathrm{~s} / \mathrm{d}$ Selesai

Tempat

Kwarda Lampung

\section{Wawancara:}

Narasumber : Bpk. Sidik Purnomo

Jabatan : Manajer Gedung dan Buper Kwarda Lampung

Pewawancara : Wina Sagita

Juru Tulis : Wina Sagita

Berkemah atau Perkemahan adalah salah satu macam kegiatan dalam kepramukaan yang dilaksanakan secara outbond. Kegiatan ini merupakan salah satu media pertemuan untuk Pramuka. Perkemahan menjadi salah satu cara penerapan metode pendidikan kepramukaan. Bumi Perkemahan Adalah tempat di alam terbuka, dimana para pemakai dapat mendirikan kemah-kemah untuk keperluan lainnya dan melakukan kegiatan-kegiatan sesuai dengan motivasi mereka masing-masing. Terkadang masyarakat yang ingin melakukan kegiatan berkemah masih bingung mencari tempat yang tepat. Di lampung sendiri ada banyak bumi perkemahan dan untuk melakukan peminjaman bumi perkemahan pramuka masih dilakukan secara manual. Maka dari itu saya ingin membuat aplikasi untuk peminjaman bumi perkemahan pramuka. Tujuan dari pembuatan aplikasi tersebut supaya mempermudah masyarakat dalam mencari tempat untuk berkemah, terutama bagi masyarakat luar kota.

Daftar Pertanyaan :

Q

A

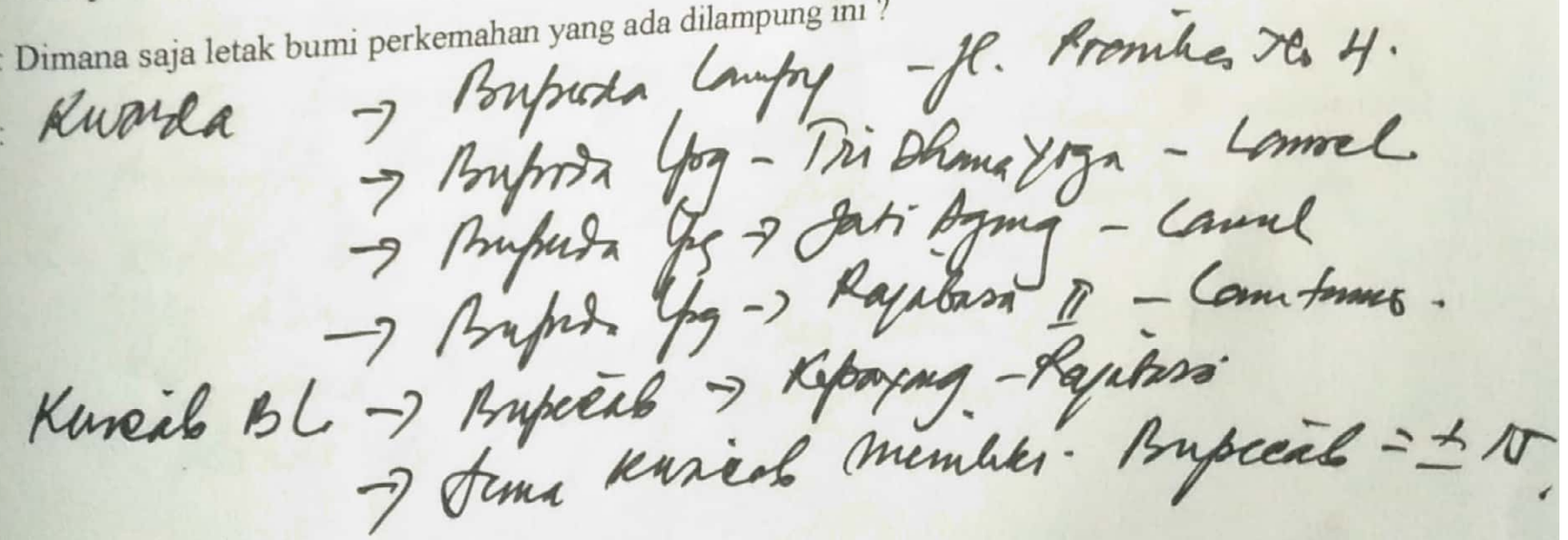


Siapa saja pemilik bumi perkemahan yang ada dilampung ini?

+ kuarla

- Nureel rel tomprs.

- Swrosta $\rightarrow$ Samar serat $\rightarrow$ B.

$\rightarrow$ Wran Abemralman - Vehutann

$\rightarrow$

Siapa saja pengelola bumi perkemahan yang ada dilampung ini ?

Ada berapa bumi perkemahan yang dimiliki oleh kwarda lampung ?

$Y$ (empat) linit Buper.

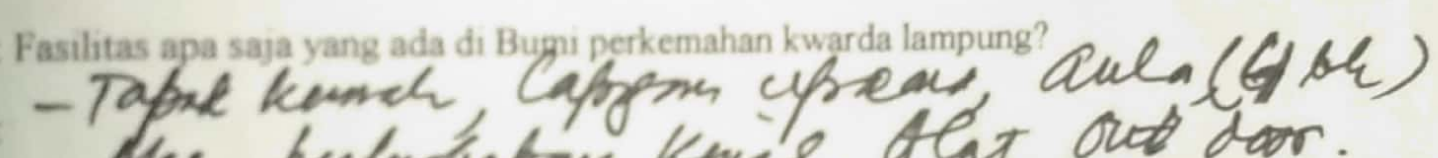

- Mes, pestugluafor knis, Alat out dor.

Q : Bagaimanakah kondisi sarana dan prasarana di Bumi perkemahan kwarda lampung ?

A : Cukup biik on mumari.

Q Apakah sebelumnya sudah ada aplikasi untuk peminjaman bumi perkemahan pramuka dilampung?

Beleme -

Q Bagaimana alur peninijaman di bumi perkemantan pramukta yang gada dir rajabasa ini?

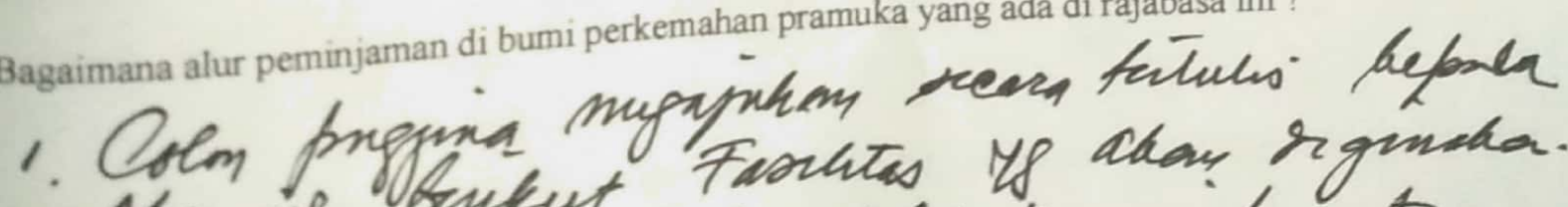

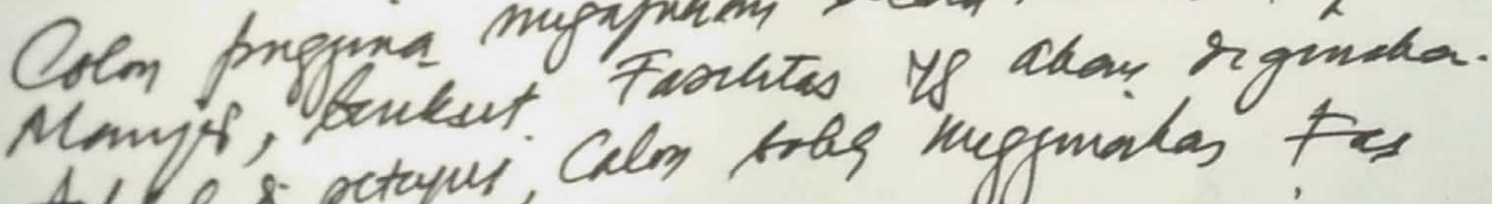

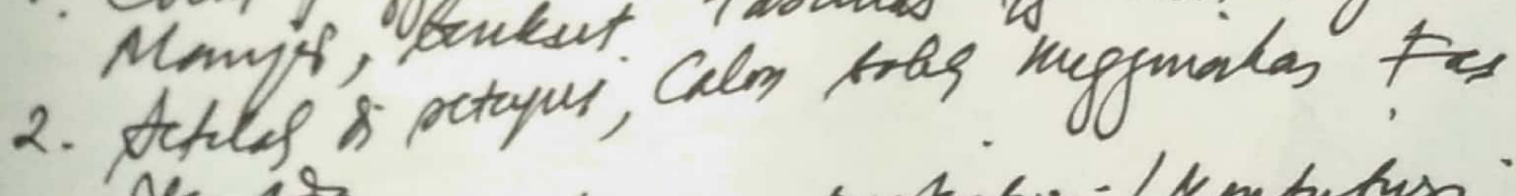

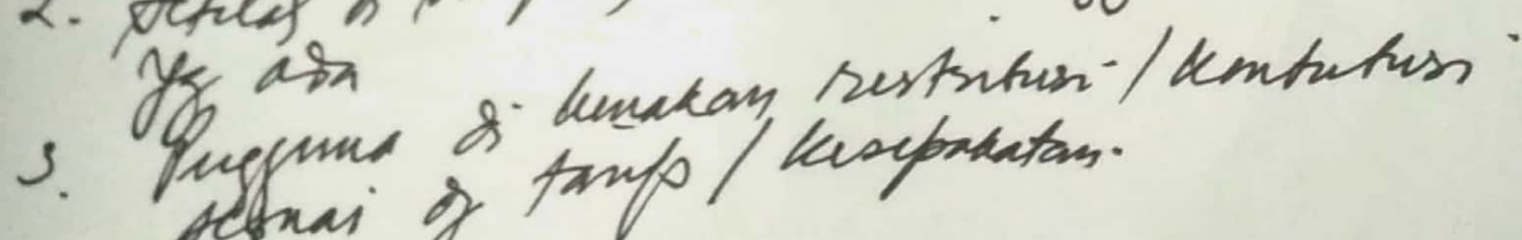

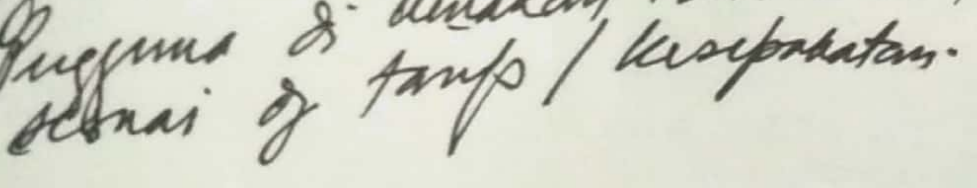


Q : Berapa luas setiap bumi perkemahan yang dikelolah oleh Kwarda Lampung ini dan kapasistas maksimal berapa jumlah calon pengguna?

- Rupars. o flta = 1000 ary,

- Tridhamen yoga $=201 / 2=0.000$ ap

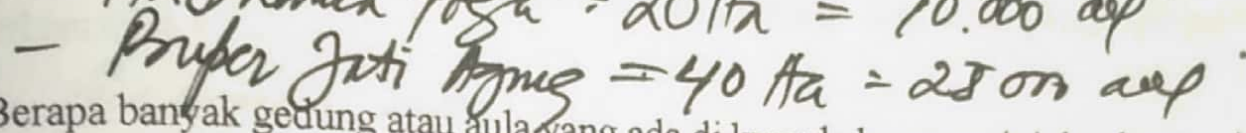
Berapa banyak geđung atau aula $y$ ang ada di kwarda lampung ini dan berapa jumlah kapasitas
tiap aula nya?

- Acer Reybasa = 2 cut = 200 as"

- Oula Bupir Jati Agng = 2 unt = 600 axp.

Q : Selama ini bagaimana cara anggota pramuka mencari bumi perkemahan untuk kegiatan

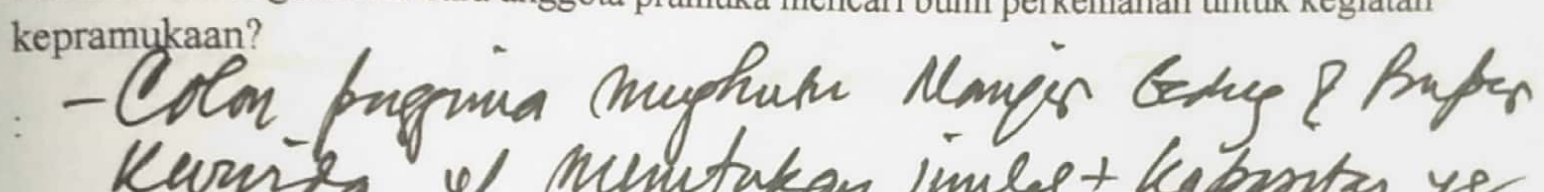

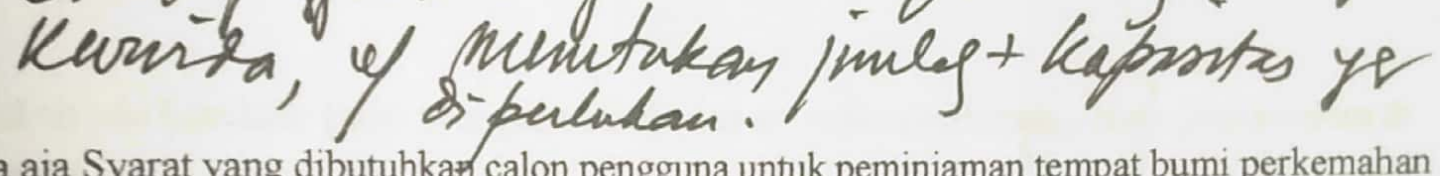

Apa aja Syarat yang dibutuhkał calon pengguna untuk peminjaman tempat bumi perkemahan ini?

- Ourat pemohmas

- Pinging. gawab Kegintas

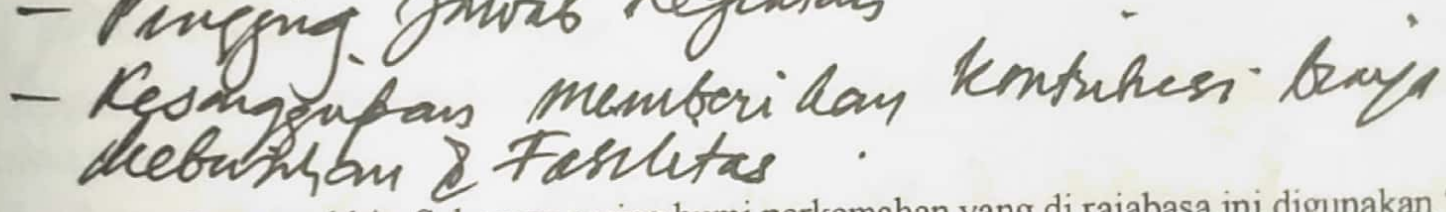

Q : Dalam 3 tahun terakhir Seberapa sering bumi perkemahan yang di rajabasa ini digunakan?

A : Rata-rata 4r keliftahus.

Q : Apakah Bumi perkemahan pramuka ini bisa digunakan oleh masyarakat umum atau hanya untuk pramuka saja?

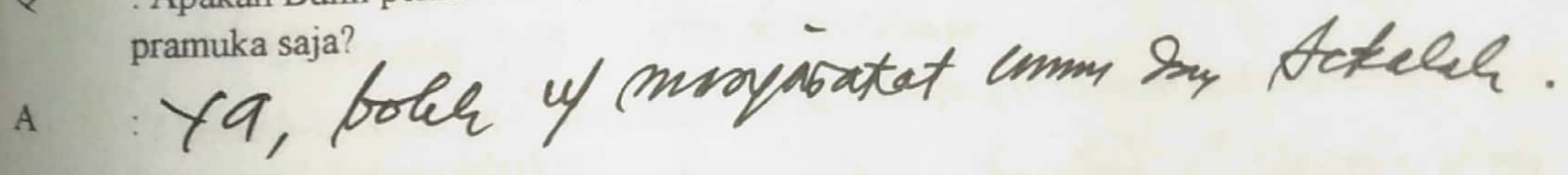

Q : Berapa biaya untukk peminjamman di bumi perkemahan kwarda lampung yang berada di

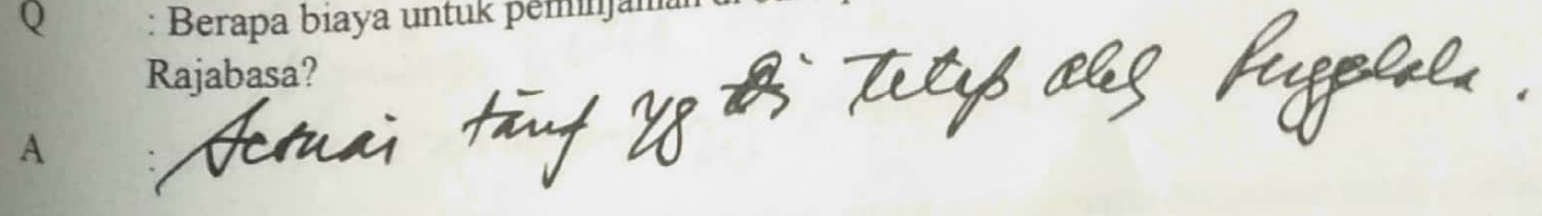

Q : Apakah selama ini proses pendataan untuk peminjaman bumi perkemahan di kwarda lampung mengalami kesulitan?

A Terah tox masale. 
Q : Apakah selama ini ada kesalahan dalam pengecekan data calon pengguna peminjaman bumi perkemahan?

A : Belan ar.

Q : Menurut bapak, Mengapa Bumi Perkemahan jarang digunakan Masyarakat untuk kegiatan perkemahan, atau kegiatan organisasi lainnya? .

A : Ditemping Kapaistes juga Varen asmya heugmien Variasi Cokesi kemal.

Q : Apakah ada kesulitan calon pengguna untuk mencari informasi tentang bumi perkemahan di lampung ini?

A : Ya, karein belin memaifretleas tromer on publekes lamyis.

Q : Apakah selama ini pengelola bumi perkemahan memberikan informasi yang akurat kepada calon pengguna?

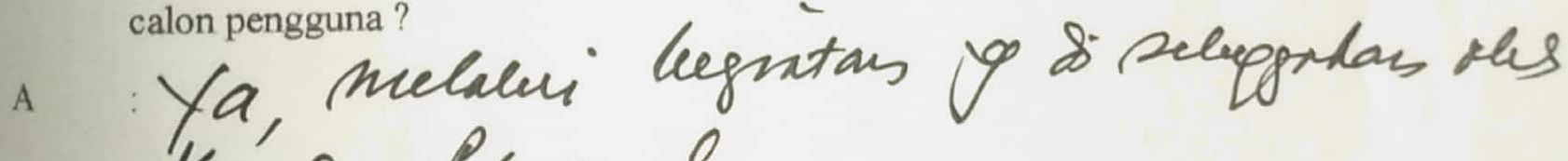
Cunsta Panule.

Q : Bagaimana cara masyarakat atau anggota pramuka mengetahui dimana saja bumi perkemahan yang jaraknya dekat dengan wilayah mereka?

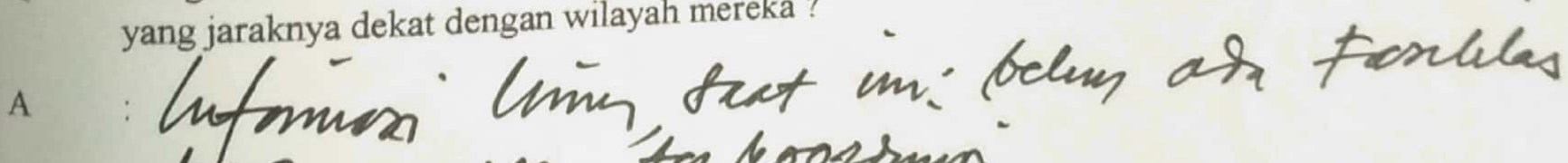
preanes og Tadeoormm"

Q : Masalah-masalah kritis apa yang di hadapi oleh pengelola bumi perkemahan di kwarda

lampung ? Tolong jelaskan torelatas Bouper C jemis on vanas. out Boral.

- Pusanam ve tabatas.

Q : Jika nantinya sudah sistem onlie apakah sistem manual masih digunakan untuk melakukan

Q : Jika nantinya sudah sistem onlie apakans
peminjaman? 

Q Apakah sistem informasi sangat berguna dalam pelaksanaan kegiatan perkemahan yang ada di
bumi perkemahan lampung?

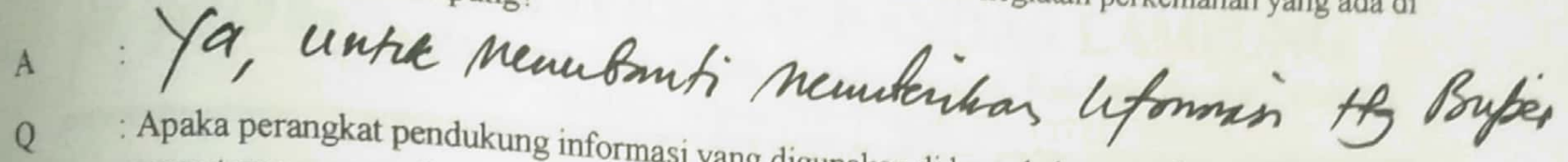
Q Apaka perangkat pendukung informasi yang digunakan di kwarda lampung harus dikembangkan
secara terus menerus?

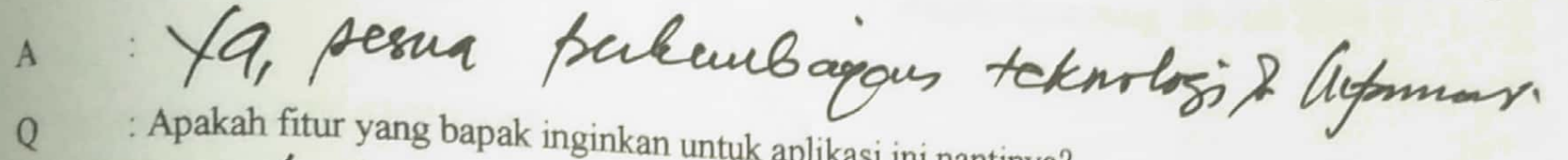

Q : Apakah fitur yang bapak inginkan untuk aplikasi ini nantinya?

- Cokasi \& Fosulitios ol jaina + Kapantas.

- Bysing borking/pemesanaur

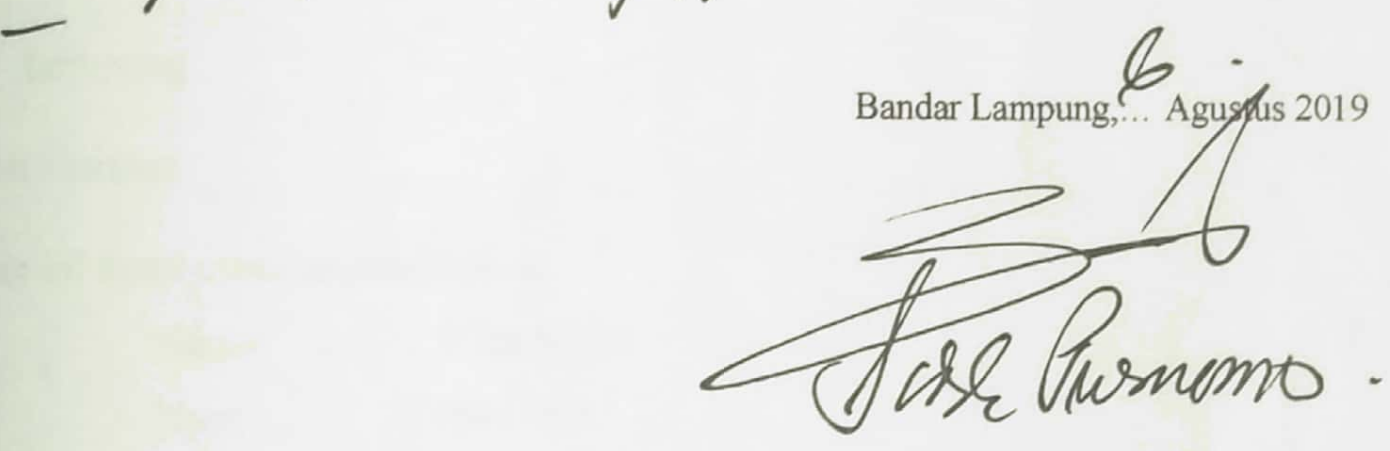




\section{FAKULTAS ILMU KOMPUTER}

UNIVERSITAS BANDAR LAMPUNG

Jl. ZA Pagar Alam No.89, Gedong Meneng, Rajabasa Bandar Lampung 35142, Telp (0721) 774626, Fax (0721) 701467

Bandar Lampung, 20 Juni 2019

Nomor : 121/FIK/SI/VI/2019

Lamp : -

Perihal: Permohonan Ijin Penelitian

Kepada Yth,

Kepala Aset Pramuka

Di -

Lampung

Dengan Hormat,

Dengan ini kami menerangkan bahwa:

$\begin{array}{ll}\text { Nama } & \text { : Wina Sagita } \\ \text { Npm } & : 16411021 \\ \text { Fakultas } & \text { : Ilmu Komputer } \\ \text { Program Study: Sistem Informasi }\end{array}$

Adalah mahasiswa kami, akan mengadakan Penelitian dalam rangka menyusun Analis Data di Kantor Gubernur Lampung. Maka dengan ini kami memohon bantuan Bapak/Ibu untuk memberikan izin melakukan riset (analisis data) di Kantor Gubernur Lampung.

Demikian harapan kami atas perhatian, bantuan dan kerja sama bapak dan ibu kami ucapkan terima kasih.

Ketua Program Studi Sistem Informasi,

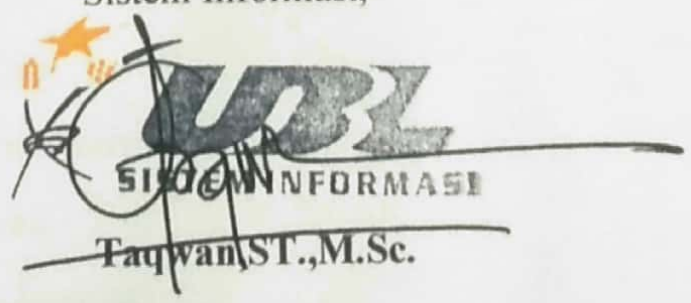


Topik Wawancara

"Aplikasi Sistem Penyewaan Bumi Perkemahan"

Waktu dan Kegiatan:

Acara ini dilaksanakan pada:

Hari / Tanggal : Kamis, 20 Juni 2019

Pukul $\quad: 12.30 \mathrm{~s} / \mathrm{d}$ Selesai

Tempat : : Kantor Gubenur

Laporan Hasil Wawancara:

Narasumber : Bpk. Johan

Jabatan : Ketua Ranting Jati Agung / Penanggung Jawab Bumi Perkemahan Jati Agung

Pewawancara : Wina Sagita

Juru Tulis : Wina Sagita

Pertanyaan Wawancara:

Q : Dimanakan tempat bumi perkemahan ini?

A : Desa Purwotanì Kecamatan Jati Agung kabupaten Lampung Selatan

Q : Siapa pemilik bumi perkemahan ini?

A : Kwarda (Kwartir Daerah)

Q : Mengapa anda menginginkan sistem aplikasi itu ?

A : Karena akses tempat ini sangat jauh dari kota dan untuk mengetahui sudah ada yang booking apa belum, masyarakat harus mendatangi tempat itu atau menghubungi pihak yang terkait via mobile. Dan mengikuti zaman yang terus berkembang kita ingin mempermudah masyarakat dalam mendapat informasi.

Q : Fasiltas apa saja yang ada di Bumi perkemahan ?

A : Aula, Lapangan Utama, MCK 40 pintu, Rumah jaga

Q : Fasilitas apa saja yang akan dikembangkan di bumi permehan ini nantinya?

A : Aula Besar, Rumah untuk tamu VIV, MCK 60 pintu.

Q : Apakah sistem tersebut berbasis Web, Dekstop, atau Mobile? 

A : Mobile, supaya penggunaan nya lebih mudah.
Q : Untuk siapa saja nanti aplikasi tersebut dibuat?
A : Untuk semua masyarakat baik itu pelajar atau perusahaan yang ingin mengadakan Family
gathering.
Q : Apakah sebelumnya sudah ada web untuk pramuka itu sendiri?
A : Sudah ada, link web nya www.pramukalampung.co.id

Q : Bagaimana alur pembookingan bumi perkemahan ini?

A :Peserta yang ini membooking tempat ini mereka mendatangi langsung ke Bumi Perkemahan Jati Agung atau bisa menghubungi pihak yan terkait.

Q : Apa aja Syarat yang dibutuhkan untuk pembooking tempat bumi perkemahan itu?

A : Syarat yang dibutuhkan yaitu: Identitas yang booking, siapa yang membooking, dari instansi mana, Waktu dan pelaksaannya, dan DP.

Q : Seberapa sering tempat ini dibooking?

A : Sebulan sekali

Q : : Apakah tempat ini bisa digunakan oleh seluruh masyarakat Indonesia atau hanya untuk masyarakat lampung saja?

A : Seluruh Masyarakat Indonesia boleh menggunakan tempat bumi perkemahan ini.

Q : Apakah marketing tempat ini bagus?

A : Belum terlalu bagus.

Q : Seberapa lama biasanya orang membooking tempat ini?

A : 2-3 hari atau lebih sesuai dengan kebutuhannya.

Q : Berapa biaya untuk pembooking bumi perkemahan ini?

A : Itu semua tergantung dari pimpinan, tapi kwartir daerah punya garis besar sendiri yang terdiri dari harian dan adajuga untuk paket. Untuk harianya itu sekitar Rp.300-500 untuk fasiltas Aula, MCK, dan untuk kebersihan.

Q : Apa saja sarana prasana yang disediakan oleh bumi perkemahan ini?

A : Outbond, Tenda, MCK, Aula, dan Lapangan. Dan panitia juga menyediakan Cathring makanan. Dan itu semua sesuai dengan kebutuhan dari peserta.

Q : Apakah sudah ada orang IT yag berkerja di bumi perkemahan ini? 
A : Sudah ada, yaitu bapak Maman sebagai sekretaris kwartir daerah. Untuk pembookingan Aula Graha Bakti Pramuka yang mengelola aula tersebut adalah Bpk. Maman.

Q : Jika nantinya sudah sistem onlie apakah sistem manual masih digunakan?

A : Untuk sistem manual mungkin masih digunkan bagi masyarakat yang belum mengetahuinya dan nantinya untuk selanjutnya diarahkan melalui sistem online.

Q : Apakah sistem informasi sangat berguna dalam pelaksanaan kegiatan yang ada di bumi perkemahan ini?

A : iya, karena itu mempemudah masyarakat mengetahui inromasi yang mereka cari.

Q : Apaka perangkat pendukung informasi yang digunakan pemerintah harus dikembangkan secara terus menerus?

A : lya itu harus, karena teknologi sekarang terus berkembang mengikuti perkembangan zaman.

Q : Apakah fitur yang bapak inginkan untuk aplikasi ini nantinya?

A : Fitur untuk memilih fasiltas seperti Aula, pemilihan untuk paket, dan contact person nya dari pak johan sendiri. 
23. Apakah Perangkat pendukung informasi yang digunakan perusahaan harus dikembangkan secara terus menerus?

24. Apakah sistem informasi yang digunanakan sebelumnya?

25. Apakah ada biaya untuk perbaikan tempat?

26. Apa saja fitur yang bapak inginkan di sistem ini?

27.

Terima kasih atas jawaban bapak dan proses wawancara ini.

Bandar Lampung, 20... Juni 2019

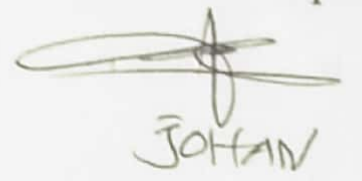

